\title{
In pursuit of corporate sustainability and responsibility: past cracking perceptions and creating codes
}

Citation for published version (APA):

de Hoo, S. C. (2011). In pursuit of corporate sustainability and responsibility: past cracking perceptions and creating codes. Maastricht University. https://doi.org/10.26481/spe.20111020sh

Document status and date:

Published: 20/10/2011

DOI:

10.26481/spe.20111020sh

Document Version:

Publisher's PDF, also known as Version of record

\section{Please check the document version of this publication:}

- A submitted manuscript is the version of the article upon submission and before peer-review. There can be important differences between the submitted version and the official published version of record.

People interested in the research are advised to contact the author for the final version of the publication, or visit the DOI to the publisher's website.

- The final author version and the galley proof are versions of the publication after peer review.

- The final published version features the final layout of the paper including the volume, issue and page numbers.

Link to publication

\footnotetext{
General rights rights.

- You may freely distribute the URL identifying the publication in the public portal. please follow below link for the End User Agreement:

www.umlib.nl/taverne-license

Take down policy

If you believe that this document breaches copyright please contact us at:

repository@maastrichtuniversity.nl

providing details and we will investigate your claim.
}

Copyright and moral rights for the publications made accessible in the public portal are retained by the authors and/or other copyright owners and it is a condition of accessing publications that users recognise and abide by the legal requirements associated with these

- Users may download and print one copy of any publication from the public portal for the purpose of private study or research.

- You may not further distribute the material or use it for any profit-making activity or commercial gain

If the publication is distributed under the terms of Article 25fa of the Dutch Copyright Act, indicated by the "Taverne" license above, 


\section{Maastricht University}

Prof. Drs. Ing. Sybren C. de Hoo

Faculty of Law

In Pursuit of Corporate Sustainability and Responsibility:

Past Cracking Perceptions and Creating Codes

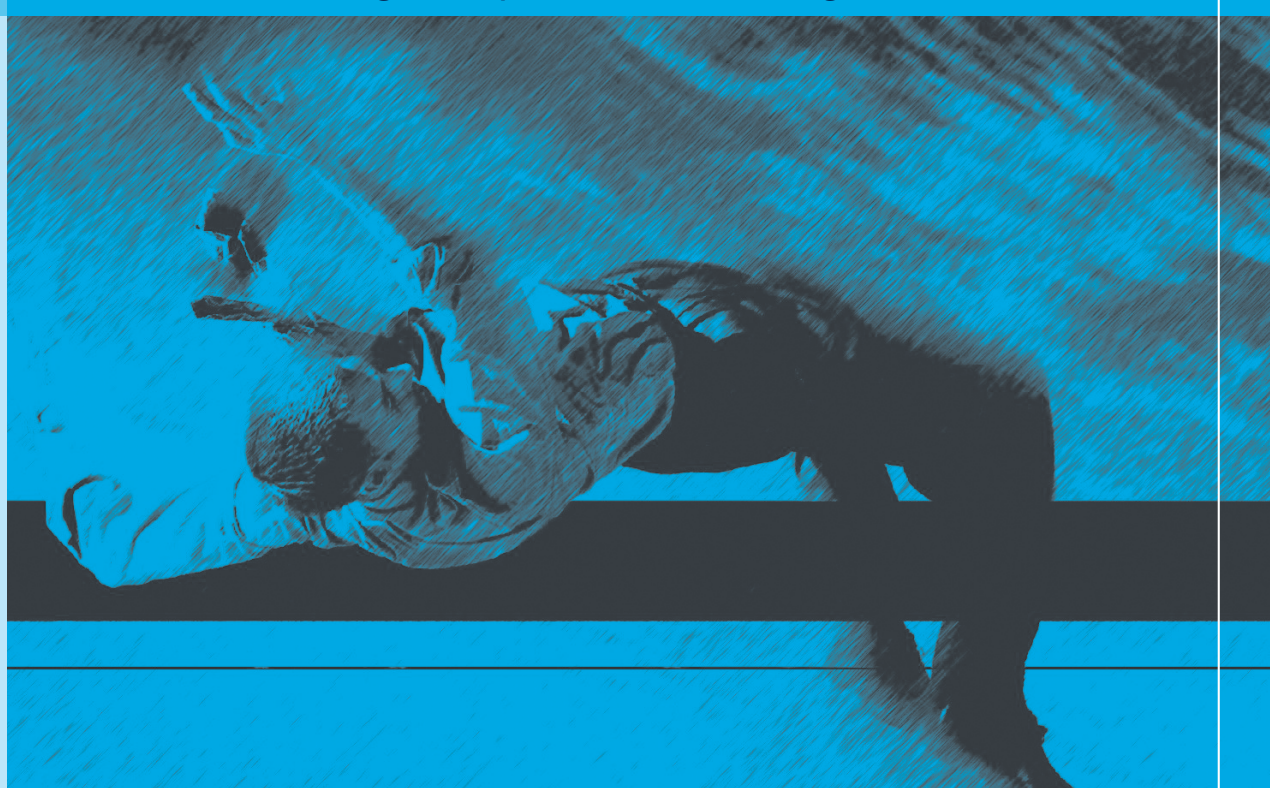




\section{In Pursuit of Corporate Sustainability and Responsibility: \\ Past Cracking Perceptions and Creating Codes}




\section{Colophon}

Design \& print: Océ Business Services, Maastricht

Cover illustration originally published in:

C. Füssler, A. Cramer \& S. van der Vegt, Raising the Bar. Creating Value

with the UN Global Compact, Greenleaf Publishing, Sheffield, UK, 2004.

ISBN: 978-905-681-3741

NUR: 820

All rights reserved. No part of this publication may be reproduced, modified, stored in a retrieval system or made public without the prior written permission of the author or publisher. 


\title{
In Pursuit of Corporate Sustainability and Responsibility:
}

Past Cracking Perceptions and Creating Codes

\author{
Inaugural Lecture \\ Delivered in an informal and abbreviated form at the acceptance \\ of the appointment of Extraordinary Professor of Corporate Social \\ Responsibility and Innovation at the Faculty of Law, \\ Maastricht University.
}

Maastricht, 20 October 2011

Sybren Christiaan de Hoo 


\section{Table of contents}

$\begin{array}{ll}\text { 1. Introduction } & \mathbf{7}\end{array}$

2. Sustainable development: the necessity for an integral approach $\quad \mathbf{1 3}$

3. Corporate social responsibility: from taking responsibility to $\mathbf{2 1}$ focusing on company-specific content

4. Cracking persistent perceptions $\quad 37$

5. A plea for a stronger regulatory approach $\quad \mathbf{5 9}$

6. The significance of the foregoing for my work at ICGI 65

7. Word of thanks 67

$\begin{array}{lr}\text { Appendix } 1 & 69\end{array}$ 


\section{In pursuit of corporate sustainability and responsibility: past cracking perceptions and creating codes}

\section{Introduction}

Esteemed Rector Magnificus and Madam Dean of the Faculty of Law, dear colleagues, family and friends, ladies and gentlemen,

\section{An unexpected adventure}

In retrospect, preparing this lecture has turned out to be an unexpected adventure for me. Once again I gave considerable thought to times gone by, the current state of affairs, the pressing issues of today and the challenges posed by sustainable development and corporate social responsibility. Both these terms involve three - frequently regarded as conflicting - dimensions: the quality of living conditions (people), quality of the environment (planet), and the significance of income, economic growth and prosperity (profit). Implementing this new form of entrepreneurship leads to sweeping changes in any company; changes that do not go smoothly. As an object of study this is a fascinating field of activity. When carrying out my investigations I supplemented my long-standing work experience in this field with a selection from what has meanwhile become a copious amount of available literature, films and documentaries on both themes. I also made use of earlier interviews with successful managers of corporate social responsibility programmes from a variety of organisations and companies in my preparatory work. Those interviews were held in 2010 with colleagues at the VU University Amsterdam, where I also hold a chair.?

In the more practical sense, my assignment today also required me to empathise with the various guests invited here today. You are a very widely composed audience and I certainly feel the need to offer you a captivating story. Only you can decide whether I have been successful or not.

\section{Personal motivation and approach}

I wished to make my own contribution to the emergence of corporate social responsibility from my background as a civil engineer, sociologist and environmental scientist. I did that chiefly on the basis of my inherent motivation. By that I mean the motivating force that drives you to live

Hoo, S.C. de, Groot, L.C.M., Jonge, F.H., Dommerholt, E. and Bunders, G.F., Duurzaam ondernemen: een onderzoek naar effectieve stimulering, verbreding en verankering, Vrije Universiteit, Amsterdam, the Netherlands, 2010. 
and to work; a force that absorbs energy, triggered by a short-circuit between the brain and the heart. For me, that 'click' developed from intrusive confrontations with the adverse effects of human activities; consequences that have made an enormous impact on society, mankind, nature and the environment, but also on me.

My first experience of this was in the Netherlands in the nineteen sixties and seventies. The work I was engaged in at that time was mainly focused on the issues themselves, and my experiences from that period were related to my being confronted with serious water pollution, oil discharges, botulism due to the discharge of cooling-water, and the impact of infrastructural works on society.

Somewhat later, the focus of my work in the Netherlands and other countries shifted towards an approach that concentrated on attempting to solve the issues themselves. Experiences from that second period relate to my commitment and work on future energy policy, technology assessment, cleaner production methods and making a contribution towards the implementation of corporate social responsibility in Rabobank Group and in my work in various consultancy positions.

I have always been fortunate enough to be able to develop and manage corporate social responsibility with exceptional, extremely motivated and talented colleagues, and this frequently led to interesting results that were widely discussed. On the basis of that work in $2004 \mathrm{I}$ became part of the academic community thanks to my professorship in Corporate Social Responsibility and Innovation at VU University Amsterdam. The affiliation with this magnificent university has given me a new impulse. Today, I publicly accept my chair and work at the Institute of Corporate Law, Governance and Innovation Policies (ICGI).

Entrepreneurship needs to change!

Companies must assume a greater responsibility for society, mankind and the environment. But in what form? How can it be achieved? My focus was particularly on searching for the answers to these questions, and it is not without reason that I have entitled this address "In pursuit of corporate sustainability and responsibility". The search for a new form of entrepreneurship, for a company that takes explicit responsibility for contributing towards sustainable development. A company that strives towards profit, prosperity and economic growth, while at the same time aims to improve social conditions and environmental quality. By keeping these three dimensions in mind simultaneously, entrepreneurs are able to achieve a balance in how their businesses perform. Constantly maintaining this balance in entrepreneurship is essential, and an 
'enlightened' management of any company is indispensable. Such a company gives that aim a permanent key position in its mission, policy, strategy, business model, management and performance. This is my guiding concept in its most basic form.

Over the years it has become evident to me that this new form of entrepreneurship is not simply accepted without a struggle. First of all it appears that in itself the widening of an organisation's goals can lead to a crippling conflict of interests. That a wide range of parties exercise power and influence is the order of the day. The second reason that accounts for the laborious development is the fact that corporate social responsibility also entails radical, often lengthy change processes within organisations. Here too are the stakeholders frequently seen to directly oppose one another. In the organisations I have either worked in or with on the development and implementation of corporate social responsibility I have come across both of these complicating and retarding factors. Regardless of whether I work on this theme in international organisations, in politics and the associated governmental organisations, in companies, in NGOs or in universities, these two factors crop up in various forms and different levels of intensity.

\section{On the subject of perceptions and codes}

Perceptions about the leeway companies have or do not have to manage their companies in a socially responsible manner are often based on the above factors. The development stages companies go through are explained in corporate social responsibility literature. These stages define a process in which corporate social responsibility detaches itself from the company's periphery and is brought, slowly but surely, into the core of the company. Over the years I have started to look upon this process as the successive dismantling of unfounded opinions about corporate social responsibility. I have named this 'Cracking Perceptions'.

Another seemingly endless process is also perceptible; that of 'Creating Codes' for corporate social responsibility. These codes are usually intended to make the complex term of corporate social responsibility able to be applied within the context of either a sector as a whole or an individual company. At the same time, this wave of constantly new and adjusted codes leads to 'code fatigue', to an increasing level of confusion and to an increasing level of irritation within companies. This too inhibits further development instead of encouraging it. I shall deal with cracking perceptions and how we deal with the profusion of codes later. 
Corporate social responsibility is in need of a new start

Over the past 20 years, corporate social responsibility in its present form - based on voluntary action - has not yet produced enough to be able to speak of success in terms of performance. Continuity and focus are far distant and corporate social responsibility is moving too slow, too unpredictable and is not result-oriented enough. In addition to forerunners and niche players pushing back frontiers, over the next few years more efforts will need to be focused on designing an effective mix of instruments that will encourage corporate social responsibility in the broader business community and that will support today's driving factors. This message is given insufficient attention both in relevant literature and in practice because all the attention is focused on the forerunners and the exhilarating niche players. It's there where an abundance of dynamism and progress can be seen. The small, select group of forerunners - chiefly major companies - is constantly exploring new boundaries and is improving performance year after year. Entrepreneurs focusing specifically on sustainable development are mainly testing the new sustainable business models and are working according to the latest insights.

Efforts are required to adequately develop incentives policy and allow us to say farewell to the guiding concept that corporate social responsibility must be based on voluntariness; a concept that has been dominant over the past few decades.

In the coming years, more attention must be focused on the large group of followers who at present are stuck in their performance on a rudimentary level of corporate social responsibility and are straggling behind even further. To tackle this problem, new opportunities must be developed to effectively encourage corporate social responsibility by introducing a mix of economic instruments and regulations. This must be supplemented with essential adjustments in corporate law and corporate management. The disciplines my colleagues at our Institute for Corporate Law, Governance and Innovation Policies are engaged in are connected with the further elaboration of these adjustments. 
In my inaugural address today I wish to initially focus on the issue of the necessity and possibilities of sustainable development and corporate social responsibility. I will argue that a sufficiently sound basis has been laid for corporate social responsibility thanks to having cracked the perceptions that stood in the way of progress and by creating codes over the past few decades. This basis is sound enough to develop and implement an incentives policy.

I shall then proceed to deal in succession with the following points:

- Sustainable development: the necessity for an integral approach

- Corporate social responsibility: from taking responsibility to focusing on company-specific content

- Cracking persistent perceptions

- A plea for a stronger regulatory approach

- The significance of the foregoing for my work at ICGI

- Word of thanks 


\section{Sustainable development: the necessity for an integral approach}

Sustainable development and corporate social responsibility

The term 'sustainable development' is mainly used in a wider context in the policies pursued by national and supranational governments as well as international organisations.

The term 'corporate social responsibility' is used mainly as an elaboration of sustainable development with specific responsibilities and performance requirements for companies.

Today's presentations look at sustainable development as a societal development in which social, environmental and economic dimensions are integrated and brought into balance. This is done with a view to the ambitions and needs of future generations, and it gives priority to improving the level of existing poverty and underdevelopment. Sustainable development as a concept was launched in Our Common Future $^{2}$ in 1987. The body responsible for drawing up that report, the World Commission on Environment and Development, reached the conclusion that in decision-making processes an end should be made to taking a separate approach to the three development dimensions: the social, the environmental and the economic. Failing this, the already existing imbalance will expand and further economic development will be at the cost of environmental quality. Simultaneously, the disparity in living conditions will also increase and lead to uncontrollable conflict situations. If sustainable development is to have a chance, then an integrated approach to the social and economic development within environmental preconditions is an absolute must.

Changes in society create an increasing need for sustainable development The growing need for sustainable development is closely linked to the nature, scale and speed at which societal changes take place. After all, as far back as the beginning of the $20^{\text {th }}$ century, population numbers, the extent of human activities and the technology available at the time, had little or no potential to change our planet earth radically and permanently. At the end of the $20^{\text {th }}$ century, the size of the population, the technologies used and the increased level of prosperity did have that impact. ${ }^{3}$ This has become quite evident in several places. At the close of the nineteen seventies we had passed the junction at which our way of life - in the global dimension - still remained within the limits of what

2 World Commission on Environment and Development (WCED), Our Common Future (also known as the Brundtland Report), Oxford University Press, Oxford, UK, 1987.

3 Brundtland, G.H., Address at Closing Ceremony of the Final Meeting of the World Commission on Environment and Development (WCED), Tokyo, Japan, 1987. 
the earth is able to provide. Since then we have started to use up our available natural capital, while large sections of the world population still have to live in poverty and under very poor social conditions.

Use the ecological footprint and human development index when taking an integral approach

Two terms were developed in the nineteen nineties that help us to obtain a better understanding of the sustainable development issue. The 'ecological footprint' is used to visualise the environmental dimension; the 'human development index' to visualise the quality of living conditions (the social and economic dimension). Since then, both these terms have found their way into numerous analyses and descriptions of the 'State of the World'. 4 Separately, but especially when combined, these terms provide the opportunity to more directly communicate the challenges that must be counteracted by sustainable development. Over the past decade efforts have been put into further developing these two terms in terms of content, methodology improvement and raising the quality of the data required. Despite the fact that discussion about both these terms and their application continues fiercely 5 they are now being used more and more and are yielding new insights.

The 'ecological footprint' brings how we use our planet - our natural capital - into the picture. Several perspectives, such as those of a country, an organisation, a company or individuals, can be used to determine the ecological footprint. The ecological footprint corresponds to the number of hectares of biologically productive area needed to supply raw materials for consumption and to cope with the ensuing residual waste and emissions. It can be calculated on the basis of data on consumption and the amount of resources needed. Other essential data relates to the areas of biologically productive land and water (agricultural land, pasture land, fishing ground/coastal waters, forestry, built-up areas) as well as to the consumption of fossil energy. The state of technology and the use and management of raw materials is also taken into account. ${ }^{6}$

\footnotetext{
4 United Nations Environment Program (UNEP), Global Environment Outlook: Environment for Development (GEO4), UNEP, Nairobi, Kenya, 2007.

United Nations Development Program (UNDP), Human Development Report 2010: The Real Wealth of Nations, Pathways to Human Development, UNDP, New York, USA, 2010. World Wildlife Fund (WWF), Living Planet Report 2006, WWF, Gland, Switzerland, 2006.

5 See for instance: Neumayer, E., Human Development and Sustainability, UNDP, Human Development Reports Research Paper, 2010.

6 http://www.footprintnetwork.org
} 
The 'human development index' illustrates the level of quality of life. This index is based on data relating to three crucial issues. The first two are associated with the social dimension and relate to health (life expectancy) and education (number of years of expected/ received education). The third issue, prosperity, relates to the economic dimension. Compiling the human development index calls for huge amounts of data that are not always on hand.

Both concepts are constantly under attack by critics who bring their content and their calculation method up for discussion. As a result, both indexes have developed further and become more robust. Both, I feel, are suitable for shedding light on several themes connected with sustainable development. I will use these later when establishing the necessity for sustainable development, but first of all I would like to deal with a number of changes that have helped to increase the amount of attention now given to sustainable development.

\section{Changes in nature and the environment, the environmental dimension}

Radical changes have taken place in the $20^{\text {th }}$ century in terms of the quality of nature and the environment. These changes relate to the atmosphere, the climate, soil, rivers and oceans, the world of flora and fauna and their mutual relationships. This partly concerns foreseeable effects, but also unintended and unexpected effects caused by activities undertaken by us humans.

Key resources - non-reproducible resources - such as the available (highquality) land, (fossil) energy, (high-quality and consumption safe) water and biodiversity are becoming more scarce. ${ }^{7}$ Conflicts about natural resources are on the increase ${ }^{8}$, and as far as our joint 'ecological footprint' is concerned, we are way beyond the earth's capacity worldwide; mankind is simply demanding much more than the earth is able to provide. ${ }^{9}$ The consequences are immense and some irreversible..$^{10}$ This situation has even worsened considerably since the publication of Our Common Future in 1987.

\footnotetext{
7 Keijzers, G., Lenen of Stelen van de Toekomst? Investeren in duurzaam ondernemen, inaugural address Nyenrode University, the Netherlands, 2000.

8 United Nations Environment Program (UNEP), Global Environment Outlook: Environment for Development (GEO4), UNEP, Nairobi, Kenya, 2007.

9 Global Footprint Network, 2010 Annual Report, Oakland, California, USA, 2011.

10 United Nations Environment Program (UNEP), Global Environment Outlook: Environment for Development (GEO4), UNEP, Nairobi, Kenya, 2007.
} 
How much of the earth's surface do we have available for the production of raw materials for the human consumption of products and services and allows us compensate their effects. Figure 1 shows a 'shrinking' earth," resulting in particular from the increase in world population. I see this as a fascinating way to show that the average available productive area required to meet our needs is on the decline (global hectares per head of global population). That figure was still approximately 7.9 (global hectares per head) in 1900. In 1961, the figure was approximately 4.5 and in 2003 it was in the region of 2.0. At the moment (2011) it is about 1.8. In view of the anticipated further growth in world population, the average available area will decline even further to approximately 1.6 in 2050.

Figure 1: A 'shrinking' earth (Source UNEP, Global Environment Outlook 4, 2007)

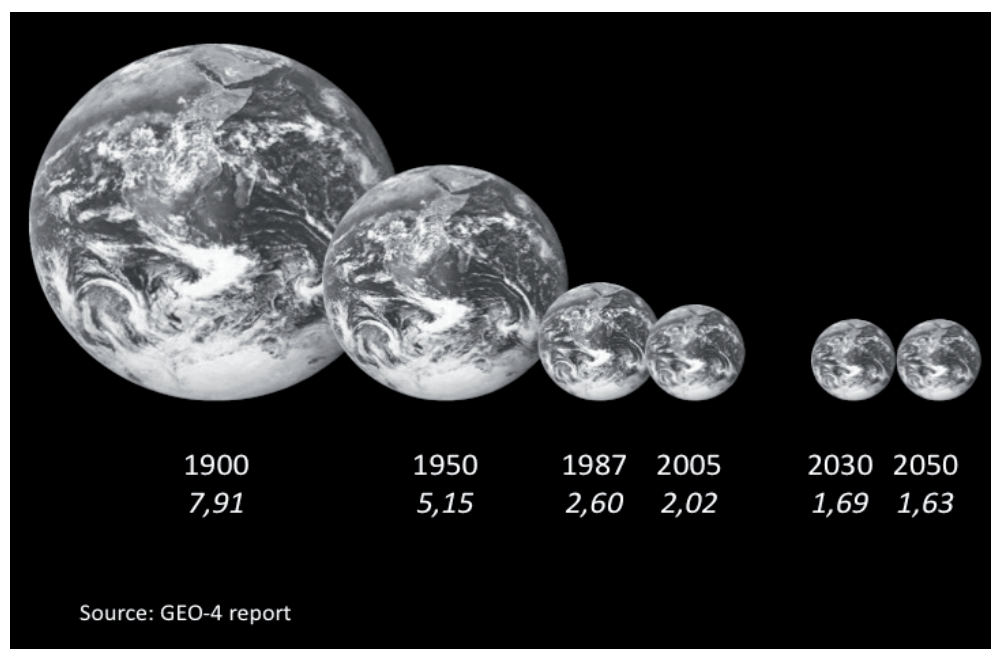

How the available capacity of the world relates to the area currently needed in different regions is illustrated in Figure 2. This figure shows the 'ecological footprint per region' based on the values in 2003. ${ }^{12}$ The available capacity per person at that time was approximately 2 (global hectares per person). This means that EU countries with an ecological footprint of an approximate average of 5 (global hectares per head) at that time already needed 2.5 times the area available per person to be able to satisfy their needs.

$" \quad$ United Nations Environment Program (UNEP), Global Environment Outlook: environment for development (GEO4), UNEP, Nairobi, Kenya, 2007.

12 World Wildlife Fund, Living Planet Report 2006, WWF, Gland, Switzerland, 2006. 
In North America, where the ecological footprint is approximately 9 (global hectares per head). This is about 4.5 times the area available per person. Average global utilisation has meanwhile increased to 1.5 times the available area per person (2010). In other words, we need 1.5 times our world to be able to meet our collective consumption and production needs.

Figure 2: Ecological footprint by region in global hectares of productive area per person, 2003. Sources: UNEP, Global Environment Outlook 4, 2007 and WWF, Living Planet Report, 2006

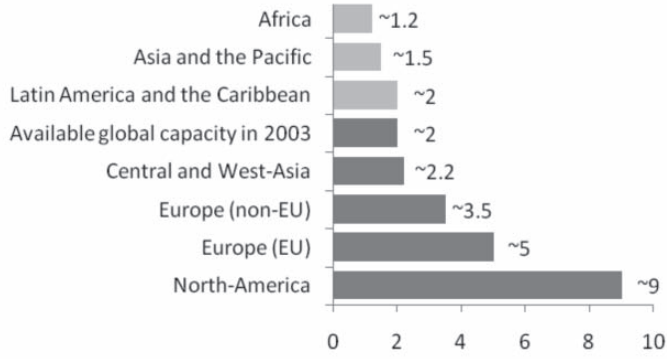

Changes in the social and economic dimension, the quality of life

Developments in the social dimension can be typified with the key indicators used in the 'human development index'.13 These indicators are: health (life expectancy), education and living standards. An unprecedented improvement took place in each of these dimensions in the $20^{\text {th }}$ century. Nevertheless, if we take a look from the global perspective we see that these developments are not equally distributed in terms of country and rate of development. They first took place in North America and Europe. Of more recent date we have seen improvements in parts of Asia and Latin America. The human development index in the countries concerned is above the 'high human development' score (the index value is then above o.66) and the index score for several countries has already passed the point of 'very high human development' (an index above 0.76). Whereas considerable differences can be seen both among and within continents and countries, the general line is shown in the index.

The huge social development problems with low to very low scores on the 'human development index' are concentrated in parts of Asia, Latin America and almost the whole of Africa.

13 United Nations Development Program, Human Development Report 2010: The Real Wealth of Nations, Pathways to Human Development, UNDP, New York, USA, 2010. 
These social problems are known to have mutually reinforcing factors such as:

1. extreme poverty and hunger;

2. limited access to (primary) education;

3. bad health situation caused by the poor quality of food, atmosphere, water, working conditions and health care;

4. discrimination on the basis of gender, race, skin colour, sexual orientation and/or religion. In the aforementioned areas there is an extremely limited level of prosperity and ditto economic development and quality of life. Large sections of the world population live below what is regarded by the international community as an acceptable level of development.

Typifying sustainable development from 3 dimensions: social, environmental and economic

Figure 3 shows the ecological footprint in combination with the 'human development index'. The vertical axis shows the ecological footprint score; the horizontal axis the 'human development index' scores. The dots in this figure represent the country scores in 2007; the dot colour indicates the region where the country is located. Each dot shows the position of a country in terms of its combined score on the ecological footprint and 'human development index." ${ }^{14}$

Figure 3: Ecological Footprint and Human Development Index.

Source: Global Footprint Network, 2010 Annual Report.

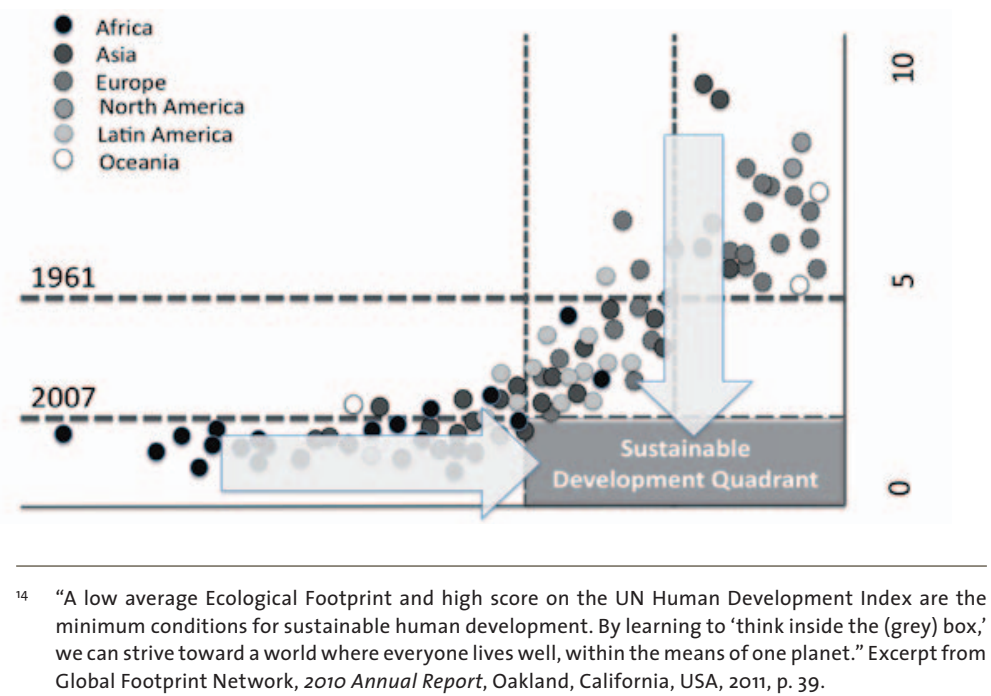


The grey rectangle at bottom right indicates the area in which the combined value should lie if there is to be any question of sustainable development. Within that area, a low score on the ecological footprint is combined with a high score on the UN 'human development index'. The conditions for sustainable development are met in the grey quadrant. This represents a situation in which people are able to lead a qualitatively 'dignified' life and at the same time remain within the limitations of the earth. Sustainable development is all about the process in which we learn to think and perform within that grey rectangle. Figure 3 also illustrates how far distanced we are from achieving this at the present time: the sustainable development quadrant is virtually empty.

The above allows me to make it clear that large sections of the global population will still need to take a huge step forward in order to improve their living conditions. This is evident in the score on the 'human development index' which is indicated by the arrow from left to right. Another aspect shown quite clearly is that the greater the effort to clear the disparities on the 'human development index', the larger the ecological footprint. Ultimately, this surpasses acceptable values by far. Climate change, water, soil and atmospheric pollution, water shortages, overgrazing, erosion, desertification, species threatened with extinction, deforestation, overfishing, etc., are apparently not the problem itself but symptoms of an underlying dynamism: the strife towards prosperity and economic growth within the current production system leads to far more being demanded of the earth than the earth is able to provide.

This illustrates the challenge that has to be solved by means of sustainable development: in which we ensure that solving the problem on the one dimension does not intensify the problem on the other dimension. In order to achieve sustainable development we must make sure that countries are able to make progress in the awareness that only a limited physical area and a finite amount of (renewable) natural resources are available. This is a necessity and will continue to be the challenge for the next few decades. ${ }^{15}$ On the basis of this observation I will now look for the translation of sustainable development into a manageable concept for the business community as a whole and for individual companies.

15 United Nations Development Program (UNDP), Human Development Report 2011, Sustainability and Equity: a better future for all, UNDP, NY, USA, to be published November 2011. 


\section{Corporate social responsibility: from taking responsibility to focusing on company-specific content}

In many lectures on corporate social responsibility no thought is given to the snares and pitfalls that lie in the definition and interpretation of the actual content. That is soon regarded as 'boring'. While this is quite possible, as soon as the subject is taken up and made tangible within a company it then apparently becomes exciting. Managers of corporate social responsibility programmes in companies ${ }^{16}$ speak of 'evading giving full attention' to the definition by using the euphemism of 'not very smart'. Their motto is: devote attention to what is and what is not included in corporate social responsibility and indicate how much weight must be attributed to those various aspects in corporate policy and the company's performance. This is one of the keys to success.

This is all about questions like: Where does the responsibility of our company begins and ends? How far outside the gate of our production facility we have to take responsibilities? What are the issues involved? What about our responsibility in the production chain of our products and of the raw materials used? Do these responsibilities go all the way back into primary production and even to actual practices of our suppliers? What is our responsibility in the user phase of our products? For example, these questions do play an important role in the production chain of agricultural commodities (such as soy, palm oil, sugar cane, cacao, wood, etc.). The priorities and investment decisions

alter substantially as soon as a company accepts a broader responsibility for sustainable development. The environmental, economic and social considerations of these full product chains are given consideration when making decisions. New issues are brought prominently into the picture and call for a comparative assessment in the full production chain. I experienced the importance of these questions in my work for Rabobank Group in relation to the financing of palm oil production in Malaysia or soy production in Brasil.

This makes clear that a company wishing to contribute towards sustainable development must first take on 'new' responsibilities and review its business as usual.

16 Hoo, S.C. de, Groot, L.C.M., Jonge, F.H., Dommerholt, E. and Bunders, G.F., Duurzaam ondernemen: een onderzoek naar effectieve stimulering, verbreding en verankering, Vrije Universiteit, Amsterdam, the Netherlands, 2010. 
As soon as these responsibilities are accepted they can radically change the content of management and performance. This process is easily shown as follows:

Sustainable development $=$ essential $\rightarrow$ companies take responsibility for contributing to sustainable development $\rightarrow$ companies adapt management content $\rightarrow$ companies adapt their performance.

I will first deal with whether companies do or do not assume new CSR related responsibilities.

Assuming responsibility by companies

My colleague, Jan Eijsbouts, and I impress on our students that realising sustainable development is out of the question if companies fail to actively cooperate. The increasing market and political powers of multinational companies and their explosive increase in number, makes this even more urgent than before. That development was made possible by reducing trade barriers and promoting opportunities to make direct business investments in foreign countries.

The number of multinational companies has increased by a factor upwards of ten over the past forty years. In 2007 the counter already showed 77,000 and in that same year 50\% of the 100 largest economies of the world is a multinational company. Not only their number and size but also the influence these companies have is quite substantial. The turnover achieved by multinationals is frequently a multiple of the Gross Domestic Product of the countries in which they operate and are required to negotiate their terms of production. ${ }^{7}$

Over the past few decades sustainable development has become one of the crucial developments in society that companies must absorb to retain acceptance in society. The pressure to do just that is part of the specific relationship between society and enterprise: that of reciprocity. Society offers a management framework, sets social goals and provides a system of laws, safety, education, health care and physical infrastructure.

17 Eijsbouts, A.J.A.J., 'Ruggie's law: filling the human rights' governance gap for mutinationals in public international law', in: Met Recht, opstellen over privaat- en ondernemingsrechtelijk ondernemingsrecht, aangeboden aan Theo Raaijmakers, Kluwer, Deventer, Nederland, 2009. 
In exchange for these and other advantages and privileges that companies receive from society it is expected that they make a contribution to the growth and development of that society by producing the necessary goods and services. ${ }^{18}$

It appears that the extent to which companies wish to assume responsibility for sustainable development has also increased over the past decade. In retrospect, the original resistance to assuming responsibilities for sustainable development is declining and has more or less been eliminated in the front running companies. I think that this change in opinions could be illustrated by the 180 degree change in The Economist's rating of corporate social responsibility. The Economist is a significant interpreter of opinions both within companies and for them. Let me give you an idea of what such a change looks like, and what issues play a role in that change.

At the beginning of 2005, The Economist lashed out strongly against sustainable development and its significance for companies. In a controversial 'special report' under the heading of The Good Company: capitalism and ethics's the concept of sustainable development and its business variant, corporate social responsibility, was consistently and cynically formulated as a threat to companies.

The illustration used to support this message was that of a Don Quichot from the $21^{\text {st }}$ century. To give an idea of the gist of that article I would like to paraphrase some parts of that text:

".... the one thing that all the nostrums of corporate social responsibility have in common is a dangerously faulty-analysis of the capitalist system they are intended to redeem ....." and "..... if businessmen had a clearer understanding of the mindset in corporate social responsibility and its defects, they would be better at their jobs and everybody else would be more prosperous..... good corporate citizens, and wise governments, should be wary of corporate social responsibility..... CSR is philanthropy with the money of shareholders .... The proper business of business is business. No apology required ....."

18 Dommerholt, E., Corporate Sustainability Performance: constructs, measures and investors' responses, Thesis, Vrije Universiteit Amsterdam, Amsterdam, the Netherlands, 2009.

Dommerholt, E., Kansen en bedreigingen van duurzaam ondernemen, richtlijnen voor bedrijfsvoering, Noordhoff Uitgevers, Groningen/Houten, the Netherlands, 2011.

19 The Economist, The Good Company, capitalism and ethics, NY, US, 2005. 
I well remember the excitement, the discussions and the impact that report caused in the company I was working for at the time. After all, it was already 2005 and this view had seemingly been eliminated for many years; this fierce rebirth seemed to be an anachronism. In actual fact it was a serious attack on all that was meanwhile being done in the field of corporate social responsibility in front running companies. The accusations were really something: an incorrect analysis of the economic system; entrepreneurs who apparently fail to understand the underlying ratio and were performing less well financially due to their activities; governments that should be on the alert; misplaced philanthropy with stakeholder's money, and finally: a climax that emerged from the school of economist Friedman that capped it all: the proper business of business is business. No apology required.

\section{The Economist, 2005}

- A faulty-analysis of the economic system

- Entrepreneurs don't understand the ratio of CSR and perform worse

- Governments should be on their guard

- Philanthropy with the money of shareholders

- The proper business of business is business. No apology required!

Economist

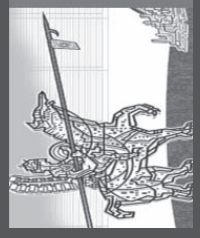

At the beginning of 2008 that message changed quite fundamentally, the tone becoming milder. The Economist again publishes a 'special report' on corporate social responsibility entitled Just Good Business: a special report on corporate social responsibility ${ }^{20}$, now defending a different view. The tone is moderately positive and the picture presented on corporate social responsibility is wider than the first report. Corporate social responsibility is now presented as: philanthropy, risk management and reputation management and an opportunity for new forms of value creation. The illustrations used to endorse this message are still woolly and in terms of content 'become accustomed to it' is the new message. 
To put across the tone of this special report I would like to present some more paraphrases:

".... businesses have eagerly adopted the jargon of "embedding" CSR in the core of their operations, making it part of "the corporate DNA" so that it influences decisions across the company ..... " and ".... a new, exhaustive academic review of 167 studies over the past 35 years concludes that there is a weak positive link between companies' social and environmental performance and their financial performance .... firms are not richly awarded for CSR but nor does it typically destroy shareholder value.

Might better approaches to CSR in future produce better return? .....analysts of Goldman Sachs reckon that by incorporating CSR into their long-term industry analysis they can beat the market ......handful of leaders, large number of followers and many laggards ..... the same names pop up again and again ....."

\section{The Economist, 2008}

- CSR is embedded in the core operations and becomes "part of corporate DNA"

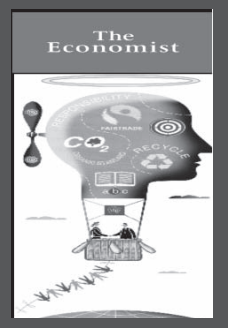

- CSR influences decisions across the company

- CSR performance shows weakpositive link with financial performance

- CSR does not typically destroy shareholder value

- CSR might with better approaches produce even better financial returns in the future

- CSR incorporated into long-term industry-analysis of Goldman Sachs analysts

- Handful of leaders, large number of followers and many laggards

Corporate social responsibility is presented as a concept which is embedded in the company and influences corporate decisions; this has a positive impact on a company's financial performance; does not destroy the shareholders' value; probably even offers the opportunity to achieve an even better financial performance in the future. This report and the change in mindset is illustrative of all that must actually be done in a company as soon as corporate social responsibility is taken seriously. 
I have on several occasions played a role in trying to achieve just that. It is a process that follows a bumpy course.

What I want to show by my example from The Economist is the change in mindset from threat to opportunity and the widening of view on corporate social responsibility. In this example, the view is widened from misplaced philanthropy to a mix of four aspects: philanthropy, risk management, reputation management and the creation of new value. The front running companies have accepted sustainable development with open arms; they have assumed their 'new' responsibility and translated it into corporate social responsibility. I keep both these The Economist specials in my library as tangible 'proof' that assuming responsibility for sustainable development in companies as a basis for corporate policy is of very recent date, and still fragile.

From sustainable development to the term corporate social responsibility A company can generally do absolutely nothing with the concept of 'sustainable development' as it was originally defined. That definition of sustainable development is:

"Sustainable development is a (worldwide) development (of society) that meets the needs of the present without compromising the ability of future generations to meet their own needs." ${ }^{21}$

This definition - if I may make an understatement - does not provide the explanation on which to base corporate policy just like that. The first requirement for obtaining wider acceptance is therefore to develop a concept which is easier to apply and is geared towards a company. Corporate social responsibility has turned out to be a more appropriate term. It must be given a content which is tailored for use by companies; interesting for companies and can be used to give direction and form to corporate social responsibility in day-to-day practice.

Let me first take a look at the word 'responsibility' in corporate social responsibility. Running a business in this way starts out with the responsibility a company takes with regard to the society in which it operates. There is constant tension at the interface between the expectations and responsibilities of society on the one hand, and

21 World Commission on Environment and Development, Our Common Future, United Nations, NY, USA, 1987 . 
those of companies on the other. Four sorts of responsibility assumed by companies can de distinguished here as: economic, legal, ethical and philanthropic. The many studies devoted to these company responsibilities make it plausible that they are ordered hierarchically. ${ }^{22}$ This hierarchy is often presented as a 'pyramid' of responsibilities and is often used in business practice. This triad is linked as follows:

Society's expectation that a contribution is made towards sustainable development $\rightarrow$ taking that responsibility by running the company in a socially responsible manner $\rightarrow$ giving expression to this in all operational processes, products and services and overall performance.

Figure 4: Characteristics of Corporate Social Responsibility; from the expectations of society, to responsibility, to performance

Sources: Caroll, A.B., 1979 and 1991, Dommerholt, E., 2009 and Visser, W., 2011

\section{Expectation $\rightarrow$ Responsibility $\rightarrow$ Performance}

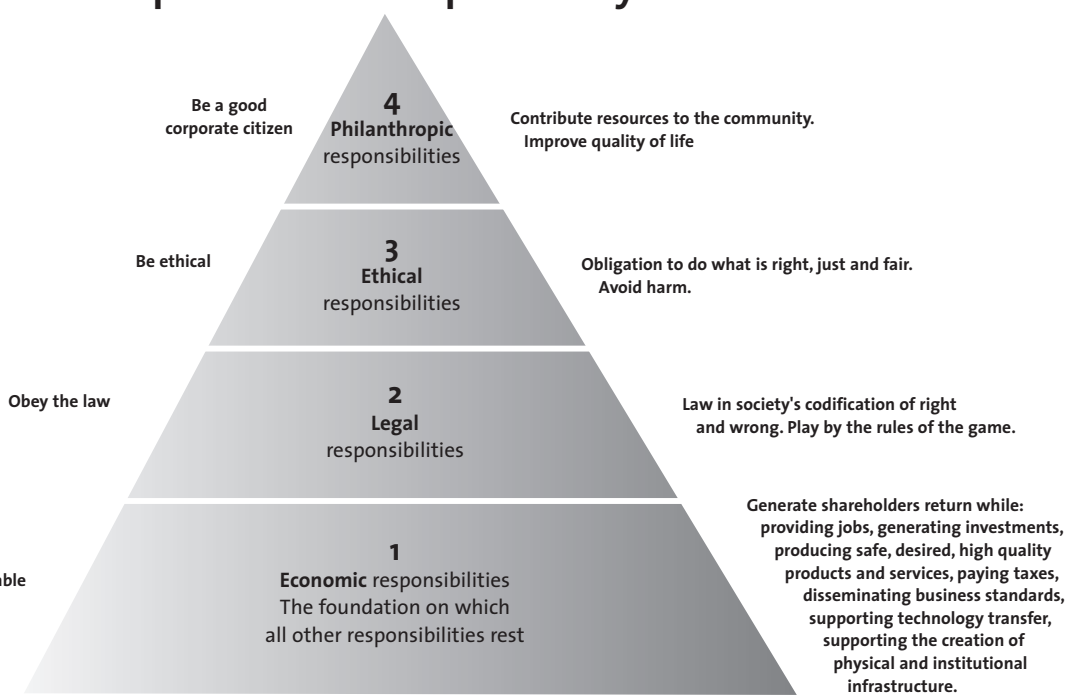

22 Dommerholt, E., Corporate Sustainability Performance: constructs, measures and investors' responses, Thesis, Vrije Universiteit Amsterdam, Amsterdam, the Netherlands, 2009.

Carroll, A.B., A Three-Dimensional Model of Corporate Performance, Academy of Management Review, Vol. 4, No. 4, 497-505, 1979.

Carroll, A.B., The Pyramid of Corporate Social Responsibility: toward the moral management of organizational stakeholders, Business Horizons, 1991.

For the amendment of the general validity of the hierarchy by Carroll (for instance as soon as major differences occur in welfare levels): Visser, W., The Age of Responsibility, CSR 2.0 and the new DNA of Business, John Wiley \& Sons Ltd., UK, 2011. 
John Elkington ${ }^{23}$ originated the much needed conversion of the concept of 'sustainable development' into 'sustainable entrepreneurship or corporate social responsibility'. He was able to achieve a breakthrough by using motivational language; language that appeals to the imagination. He devised the term 'Triple P'. By introducing this term he conjured up a picture of corporate performance on the three dimensions of sustainable development (see also the previous paragraph): 'People' (the social dimension), 'Planet' (the environmental dimension) and 'Profit' (the economic dimension). The result that stems from that corporate performance is given the interesting term 'The Triple Bottom Line'. Both terms were greeted with open arms worldwide, and since the end of the nineteen nineties have become standard terms. In this school of thought, corporate social responsibility is referred to as Corporate Sustainability Performance. Performance is easier to define, operationalise and measure than responsibility. Sustainability is directly linked to sustainable development.

The same conclusion was also drawn later by Dommerholt (2009).24 After making a thorough analysis of terms and concepts he too preferred to replace sustainable development for companies with the term: Corporate Sustainability Performance.

By doing this he emphasises the importance of the specific link of the actual content of corporate social responsibility with:

- enterprise (corporate),

- sustainable development (sustainability) and

- operational achievements (performance).

Elkington's views, for instance, have had an effect on the 'spirit and content' of the definition given by the SER (Social and Economic Council of the Netherlands) 25 which has been accepted with open arms. The SER (2000) uses a new term, social entrepreneurship, and the actual content of its definition has apparently been very useful for many companies.

23 Elkington, J., Towards the Sustainable Corporation: win-win-win business strategies for sustainable development, California Management Review, 36, No. 2,, 90-100, California, USA, 1994.

Elkington, J., Canibals with forks, the triple bottom line of the $21^{\text {st }}$ century business, New Society Publishers, Gabriola Island, Canada, 1999.

24 Dommerholt, E., Corporate Sustainability Performance: constructs, measures and investors' responses, Thesis, Vrije Universiteit Amsterdam, Amsterdam, the Netherlands, 2009.

25 Sociaal Economische Raad, De Winst van Waarden, Advice to the Secretary of State for Economic Affairs, The Hague, the Netherlands, 2000. 
Over the past ten years a development has been under way in which - in addition to the social, the environmental and the economic dimension - a fourth dimension of corporate social responsibility has been added, both in practice and in the formulation of theories: corporate governance.

The 'discovery' of governance as an 'essential'fourth dimension of corporate social responsibility

This development cannot be traced back to the sustainable development debate only. 'Corporate scandals' 26 of an unprecedented size and with farreaching consequences arise on a regular basis and they too made their contribution. The recent financial crises and the lessons that should be learnt from them provided new input in the importance of governance. ${ }^{27}$

Adapting corporate governance is regarded as an essential condition in order to develop corporate social responsibility at all. Governance relates to the nature of a company's supervision and management. Within the context of corporate social responsibility, governance covers (inter alia): widening the organisational goals; more independent supervision; an adapted form of management; more transparent communication and responsibility and a more extensive and more clearly specified accountability. In actual fact, over the past few years this state of mind has become inextricably bound up with corporate social responsibility; governance has become the fourth dimension. In terms of content corporate social responsibility crystallises in codes or guidelines developed by different organisations. Today, governance also has a permanent place in these codes and guidelines. In both most recent 'mothers' of codes of the 2008 Global Reporting Guidelines and the 2010 International Standard Organization's 15026000 , this elaboration of governance is given a prominent place.

In this part of my inaugural address I have shown three developments that have taken place in the views on the actual essence of corporate social responsibility and its practice which, I feel, are important. The first development is one in which companies really do accept responsibility for sustainable development conform the expectations of society. Subsequently, that responsibility is converted into corporate sustainability performance and given shape in all the company's operational activities

26 McLean, B., Elkind, P., The Smartest Guys in the Room: the amazing rise and scandalous fall of Enron, 2004.

27 Sorkin, A.R., Too Big to Fail, Inside the Battle to Save Wall Street, Allen Lane, Penguin Group, London, UK, 2009 .

Reingoud, T., Het nieuwe bankieren, De duurzame oplossingen van bankier Peter Blom, Kosmos, Utrecht, the Netherlands, 2009. 
and corporate performance. The third development is one in which corporate governance becomes regarded as an 'essential' dimension of corporate social responsibility. These developments deserve to be given a firm place in the further elaboration of the term and concept of corporate social responsibility.

Let me attempt to explain. I am quite flexible in my choice of the term we use to typify this form of entrepreneurship. At the moment, a variety of terms are used interchangeably, and I have no problem with that. These terms include:

- Maatschappelijk Verantwoord Ondernemen (term used in the Netherlands),

- Duurzaam Ondernemen (term used in the Netherlands),

- Social Entrepreneurship,

- Corporate Social Responsibility 1.0 or 2.0,

- Corporate Sustainability Performance.

However, I am less flexible with regard to the separate components that should be worked out for these terms in the concept. With all due modesty, and making use of the work of so many others, I arrive at six components that must be explicitly discussed.

These components are:

Corporate Social Responsibility is a form of entrepreneurship in which a company:

- Subscribes to the social wishes of and the necessity for sustainable development,

- Accepts and assumes responsibility for making a contribution towards sustainable development,

- Implements the necessary changes in its governance,

- Is fully alive to the interests and wishes of its stakeholders,

- Establishes those economic, social and environmental aspects of relevance to the company on the basis of widely accepted codes and integrates them in all its operational activities,

- Measures and evaluates the effects of its corporate performance and gives a transparent account thereof. 
Determine the specific content of corporate social responsibility

With these general components in mind I would like to move on to the specific content of the term corporate social responsibility. When I was first engaged in developing and executing this sort of programmes, the situation was still reasonably orderly in that respect. There were only a few, global guidelines and the wording was still limited to a few dozens of pages. It was mainly a period of developing and shaping the content on the basis of "trial and error" in corporate practice when implementing corporate social responsibility.

Today however, a company has to deal with a glut of codes and guidelines for corporate social responsibility drawn up by a very wide range of organisations. Over the past two decades there has even been an absolute torrent of codes. More than 100 different codes have seen the light of day in the last decade alone. ${ }^{28}$ This 'code mania' is still spreading in virtually every part of corporate social responsibility and in almost all major industrial sectors. This leads to 'code irritation' among companies because these codes and guidelines now cover hundreds of pages, are scarcely geared to one another, still increase in number, and lastly, appear to contain substantial disparities in terms of content.

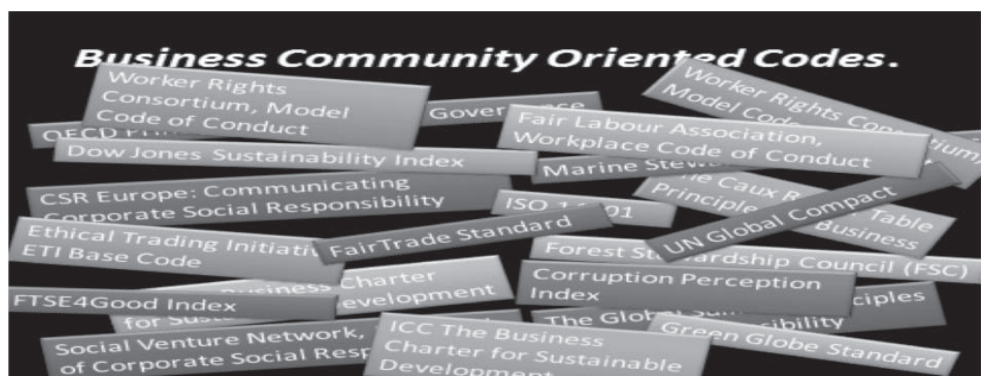

The choice a company makes for either one or several codes is a question of strategy. This is even intensified by the fact that different market parties and research institutes use their own analysis framework. Assessors of corporate social responsibility for use in financial markets, such as Sustainable Asset Management (SAM) and KLD are apparently

28 Visser, W., The Age of Responsibility, CSR 2.0 and the new DNA of Business, Wiley \& Sons Ltd., Chichester, UK, 2011. 
linked more to certain performance characteristics than can be deduced from the codes themselves. Codes and guidelines differ in terms of content, and the aspects of that content differ in significance. This makes the company's choice for a set of codes on which to base its corporate social responsibility complicated and gives it a strategic character.

To bring some order in the 'code/guideline chaos', I provide the overview below. I have included frequently used codes for corporate social responsibility and the organisations that formulated them. The codes marked with an asterisk I feel provide an adequate basis for determining the specific content of corporate social responsibility for an individual company. In my choice the following issues played a role: the reputation of the organisation concerned, the stakeholder consultation methods used, the breadth and depth of the guidelines, as well as the constant process of adjustment. By adding sector-specific guidelines, an extra impulse can be given to quality and robustness.

Figure 5: Overview of a few frequently used codes for corporate social responsibility $\left(^{*}=\text { my preference }\right)^{29}$

\begin{tabular}{|c|c|}
\hline ORGANISATION & CODES \\
\hline Global Reporting Initiative & Sustainability Reporting Guidelines* \\
\hline Organization for Economic Cooperation and Development & $\begin{array}{l}\text { OECD Principles of Corporate Governance* } \\
\text { OECD Guidelines for Multinational Enterprises* }\end{array}$ \\
\hline International Standard Organization & $\begin{array}{l}\text { ISO } 14031 \text { Management Guidelines and } \\
\text { Performance Evaluation Guidelines* } \\
\text { ISO } 26000 \text { Guidance on Social Responsibility* }\end{array}$ \\
\hline $\begin{array}{l}\text { UNEP/UNDP/ UNOHCHR/UNIDO/ILO } \\
\text { SOcial Accountability International }\end{array}$ & $\begin{array}{l}\text { Global Compact* } \\
\text { SA 8000* }\end{array}$ \\
\hline \multicolumn{2}{|c|}{ 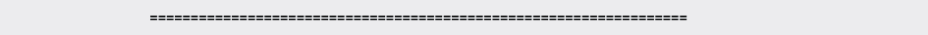 } \\
\hline $\begin{array}{l}\text { International Chambers of Commerce } \\
\text { World Business Council for Sustainable Development }\end{array}$ & $\begin{array}{l}\text { The Business Charter for Sustainable Development } \\
\text { Measuring Eco-Efficiency }\end{array}$ \\
\hline \multirow[t]{3}{*}{ Coalition for Environmentally Responsible Economies CERES } & $\begin{array}{l}\text { Winning with Integrity } \\
\text { Ceres Principles }\end{array}$ \\
\hline & Ceres Reporting Requirements for Small and \\
\hline & $\begin{array}{l}\text { Medium Sized Enterprises and Non-profit } \\
\text { Organisations }\end{array}$ \\
\hline $\begin{array}{l}\text { CSR Europe } \\
\text { Ethical Trading Initiative }\end{array}$ & $\begin{array}{l}\text { Communicating Corporate Social Responsibility } \\
\text { ETI Base Code }\end{array}$ \\
\hline Fair Labor Association & Workplace Code of Conduct \\
\hline
\end{tabular}

In the next table ${ }^{30}$ I give an impression of the substantial differences that can arise between the different codes.

29 Füssler, C., Cramer, A., Vegt, S. van der, Raising the Bar, creating value with the UN Global Compact, Greenleaf Publishing, Sheffield, UK, 2004.

Dommerholt, E., Corporate Sustainability Performance: constructs, measures and investors'

responses, Thesis, Vrije Universiteit Amsterdam, Amsterdam, the Netherlands, 2009.

Visser, W., The Age of Responsibility, CSR 2.0 and the new DNA of Business, Wiley \& Sons Ltd., Chichester, UK, 2011.

30 The recently published code ISO 26000 Guidance on Social Responsibility has not yet been included in this table.

NEN-ISO 26000 , Richtlijn voor maatschappelijke verantwoordelijkheid van organisaties, Nederlands Normalisatie Instituut, Delft, the Netherlands, 2011. 
To this end I have made use of the thesis written by Dommerholt ${ }^{31}$, who did all the systematic and endless work to be able to arrive at these insights. On the basis of a content analysis of a large number of codes, Dommerholt drew up an overview of their combined content. He distinguished between dimensions (4), aspects (22) and underlying issues (222). On that basis he also established the weight of that content which is shown for the dimensions and aspects in the column on the right in the table. This can be used as reference and measure. The table shows white boxes for those dimensions and aspects of corporate social responsibility that are not taken into consideration in certain codes. These items are taken into consideration explicitly in the one code and not in the other. There are also inconsistencies to be seen in the relative significance attached to certain parts of the content. This can be seen by the colour and the coefficient which, when combined, indicate the degree of overvaluation and undervaluation. It then becomes visible how codes can differ in terms of content and weight attributed to the different dimensions and aspects of corporate social responsibility. This should provide companies with more insight for them to make their final choice from the codes.

Table 1: differences in terms of content with some core CSR-codes and CSR-rating agencies
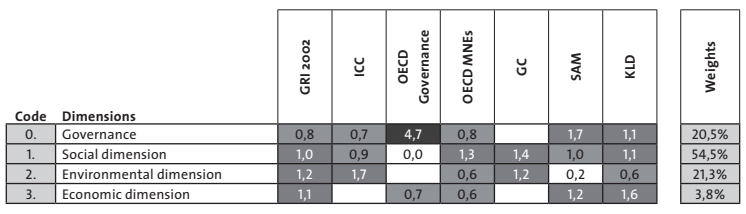

Code Aspects
\begin{tabular}{|c|l|c|c|c|c|c|c|c|}
\hline 0.1 & Overarching Principles & 0,2 & & 1,0 & 0,4 & & 0,9 & 0,2 \\
\hline 0.2 & Overarching Processes & 0,9 & 1,1 & 2,8 & 1,2 & & 2,0 & 1,5 \\
\hline 0.3 & Stakeholders & 0,7 & 0,3 & 1,3 & 0,2 & & 0,5 & \\
\hline 0.4 & Shareholders & 0,5 & 0,5 & 16,4 & 0,3 & & 1,2 & 0,2 \\
\hline 0.5 & The Board & 0,9 & 0,3 & 10,1 & 0,6 & & 2,8 & 2,0 \\
\hline 1.1 & Employees & 0,9 & 0,2 & 0,1 & 0,5 & 1,9 & 1,1 & 0,9 \\
\hline 1.2 & Customers & 1,7 & 1,8 & & 1,6 & & 0,6 & 0,9 \\
\hline 1.3 & Business partners & 0,8 & 1,4 & & 0,1 & 1,8 & 1,0 & 0,1 \\
\hline 1.4 & Community & 0,9 & 1,7 & & 3,2 & 1,0 & 1,2 & 1,9 \\
\hline 1.5 & Competitors & 1,8 & & & 4,7 & & & 2,4 \\
\hline 1.6 & Providers of capital & 6,4 & & & & & & \\
\hline 2.1 & Emissions & 0,9 & & & & & 0,3 & 0,9 \\
\hline 2.2 & Life support & 5,9 & & & 0,1 & 3,6 & & 0,8 \\
\hline 2.3 & Products and services & 0,7 & 1,0 & & 1,6 & & 0,1 & 1,0 \\
\hline 2.4 & Research and technology & & 14,5 & & 3,2 & 16,0 & & \\
\hline 2.5 & Resources & 1,1 & 0,7 & & & & 0,4 & 1,0 \\
\hline 2.6 & Transport and equipment & 0,4 & & & & & & \\
\hline 2.7 & Waste & 0,7 & 0,8 & & & & 0,4 & 0,6 \\
\hline 2.8 & Environmental conformance & 0,7 & 3,5 & & 1,0 & 1,3 & 0,2 & 0,1 \\
\hline 3.1 & Economic market value & 0,9 & & 1,7 & 0,6 & & 1,1 & 2,1 \\
\hline 3.2 & Economic performance drivers & 0,9 & & & & & 3,5 & 3,4 \\
\hline 3.3 & Externalities & 1,3 & & & 0,7 & & 1,1 & 0,9 \\
\hline
\end{tabular}
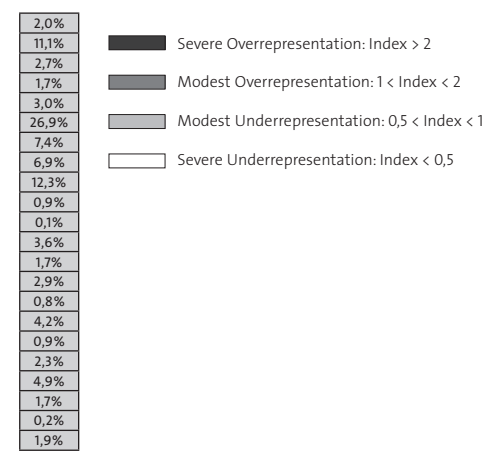

31 Dommerholt, E., Corporate Sustainability Performance: constructs, measures and investors' responses, Thesis, Vrije Universiteit Amsterdam, Amsterdam, the Netherlands, 2009. Egbert Dommerholt was admitted to the degree of doctor by my colleague, Prof. T.L.C.M. Groot, and me, and at my request drew up this table and provided the permission to use it. 
In the appendix 1 , for informative purposes I have indicated the content that corporate social responsibility in an extensive form can take on, based on the four dimensions and their underlying aspects and issues. A company-specific selection has to be made on the basis of that content. The reports on corporate social responsibility published by, for example DSM, Akzo-Nobel, Unilever, Philips Electronics, ING, Rabobank, KPN, Aegon and Post NL show how these specifics in content of corporate social responsibility have been given form with a 'Dutch touch' within these multinational companies and what future challenges are in store regarding their corporate sustainability performance. ${ }^{32}$

Establish the company-specific content of corporate social responsibility Company-specific content depends on a combination of a company's specific features, such as: company size, the sector in which the company operates, type of products and services, whether the company is listed on the stock exchange and the degree to which, and how a company is active in several countries.

The company-specific content of corporate social responsibility can be determined reasonably quickly by using a limited number of codes in a certain order. This procedure is as follows:

Figure 6: Overview of the step-by-step utilisation of some codes on the basis of which a company is able to formulate a robust company-specific content of corporate social responsibility

Input used

1. OECD guidelines and Global Compact

2. Sector-specific codes

3. Global Reporting Initiative and ISO 2600

4. Rating agencies such as SAM and KLD

5. Core performance indicators

6. ISO, SA 8000, Global Compact

7. Global Reporting Initiative (2)

\section{Result}

$\rightarrow$ global content

$\rightarrow$ sector-specific content

$\rightarrow$ reports on suitability / type of management

$\rightarrow$ make performance rating robust

$\rightarrow$ determine KPIs, weigh and prioritise

$\rightarrow$ increase potential management control

$\rightarrow$ form and content of reports

32 See the annual sustainability reports or annual social reports of these companies. See also the Volkskrant of Friday 9 September 2011, Nederlandse bedrijven duurzaam. This article discusses the rating of these companies by Sustainable Asset Management in the context of the Dow Jones Sustainability Index 2011-2012. 
Within the company context these codes are used to answer questions such as: which is the relevant global content we have to consider; what is already available with regard to sector-specific content and issues; what is expected from a reporting point of view; how can we at the same time become sustainability-rater-robust; which changes have to be made in management information systems and how can the level of dataassurance be improved? Nowadays - since 2011 - also ISO 26000 provides a systematic approach to these types of questions. Subsequently, it is a matter of getting down to the implementation stage, keeping a close eye on the priorities that have been set. Progress is made by means of improvement cycles and slowly but surely the performance level in corporate social responsibility improves. Stakeholders, internal and external verification, reporting and rating all play an indispensable role in this process.

In this part of my inaugural address I have described that it is no longer a question of whether companies must implement CSR, but rather a question of how it is implemented. Therefore I provided you with some insights about what the content of Corporate Social Responsibility currently is. Now we move on to the ways in which CSR is given shape, to some persistent perceptions that block progress of CSR implementation and how these perceptions are dismantled. 


\section{Cracking persistent perceptions}

Information in the CSR literature is usually positive regarding the pace at which corporate social responsibility is developing. This is the case if we look at the small leading group of companies. As soon as that selective magnifying glass is removed, however, and we take a look behind us there is little movement to be seen. The gap between the small group of leaders and the main group of companies is even becoming wider. Not only is it the progress that is disappointing, but the results of the efforts are also difficult to see. The score in 'state of the world' studies on various indicators of the social and environmental dimension is still on the decline. The recent shift in vision I illustrated with The Economist shows how recent it is that the acceptance of corporate social responsibility as a component of today's management has been given slightly wider - but still fragile - support. I do not regard myself as a pessimist, but I have enough reason to critically accede to the optimism regarding pace and amount of corporate social responsibility. This is even more so given that the expectation is that the next few decades will show the same picture of slow progress and disappointing effects. 33

Why is this process going so slowly?

Firstly, the process of change is typically an uphill battle. ${ }^{34}$ The start of this process was in the nineteen eighties when there was a growing conviction that the traditional method of regulating and managing environmental issues with 'end-of-pipe technologies would fail to come up with an adequate solution. At that time, specific technologies were applied at the end of production processes in order to keep soil, water and air pollution within the norms. These were applied in such a way that the existing processes could remain more or less unchanged. In essence, these end-of-pipe technologies are not productive investments and have a cost increasing effect. They could also be semi-solutions because the environmental load can be shifted from land to water or the atmosphere and vice versa.

33 Visser, W., The Age of Responsibility, CSR 2.0 and the New DNA of Business, John Wiley \& Sons Ltd, Chichester, UK, 2011

34 This is the case in the Netherlands and in other countries. Each country uses its own firm battering rams in that uphill battle; battering-rams to which we are so much indebted. With regard to the Netherlands, on the basis of my own experience I inevitably think of dozens of people with whom I have had the pleasure of working with for a long time: at the interface of politics and science, in societal organisations, in the business community and in international organisations. With perseverance and calmness they have been able to get new options placed on the agenda. That was quite often 'one hell of a job'. 


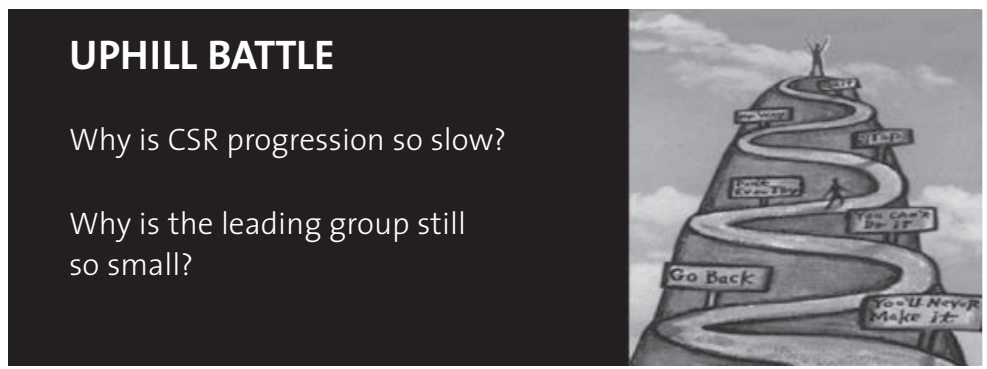

The idea was that the road to getting out of this deadlock could be found by successfully implementing new, more integrated solutions of cleaner production and clean technology so as to prevent waste and emissions. In addition to this environmental dimension, the social dimension was also brought into the process later. However, the business community in the wider sense was evidently encapsulated in the restraining powers of investments that had already been made, existing legislation, production processes, products and services, or could not be convinced of the potential of this new approach. In the contrary, adverse effects of corporate social responsibility were anticipated, both for companies themselves and for their shareholders.

Such perceptions considerably slowed down the pace at which corporate social responsibility could be brought into the actual core of a company. These perceptions had to be stripped of their dominance one by one with solutions developed by leading companies in association with scientists, stakeholders and government representatives. In my view these perceptions have the character of a hurdle race. New concepts were developed, experiments carried out and demonstration projects were launched. The essence of this consists of gradually introducing improvements, constantly raising the bar, using and developing new technologies, pursuing innovation, etc. Interesting results have been achieved by using this approach. 35

35 See, for example, the theses of:

Berkel, C.W.M. van, Cleaner Production in Practice, Methodology development for environmental improvement of industrial production and evaluation of practical experiences, IVAM Environmental Research, University of Amsterdam, Amsterdam, the Netherlands, 1996.

Dieleman, H., De Arena van Schonere Productie, mens en organisatie tussen behoud en verandering, Uitgeverij Eburon, Delft, the Netherlands, 1999.

Hemel, C.G. van, Eco-design empirically explored: Design for Environment in Dutch small and medium sized enterprises, Design for Sustainability Program publication, Delft University of Technology, Delft, the Netherlands, 1998. 
Over the years, these persistent perceptions have been cracked one by one, and today they can be convincingly contradicted on the basis of the knowledge and experience that has since been obtained. Let us take a closer look at that situation. I will now go into more detail about several of these persistent perceptions - which I consider key - in relation to

1. Production processes,

2. Products and services, and

3. Management and performance.

\subsection{Perception 1: A more sustainable performance of production processes increases the costs and poses $a$ threat to competitiveness}

Increasing attention paid to adapting production processes on the basis of corporate social responsibility took place more than twenty years ago (in the mid-1980s). Originally the focus was on the environmental and economic dimensions, the social dimensions were integrated some years later. At that time the persistent perception within the business community was:

A more sustainable performance of production processes increases the costs and poses a threat to competitiveness.

The dismantling of this perception started in several proactive companies, which simply followed their enlightened self-interest. They were responsible for giving shape to experiments that substituted the end-of-pipe approach with a preventive approach in the production process. In those days, the multinational, 3M (Minnesota Mining and Manufacturing Ltd.), ${ }^{36}$ was a shining example of that approach. Already in the mid-1970s this company had developed a new strategy to meet the more stringent environmental requirements while at the same time achieving substantial financial benefits. Pollution Prevention Pays very soon became the slogan of this company as an indication of its environmental policy. But it soon became evident that this was an approach that could be adopted and used more widely within the business community. That led to numerous activities being undertaken by other stakeholders that brought this approach to a wider base and a broader field of application.

${ }_{36}$ For more information, visit current $3 \mathrm{M}$ websites such as: http://solutions.3m. com/3MContentRetrievalAPI/BlobServlet? locale $=$ en_US \& Imd $=1234968551000 \&$ assetld $=118061$ 0148373\&assetType =MMM_Image \& blobAttribute $=$ ImageFile or http://solutions.3m.com $/ \mathrm{wps} /$ portal/3M/en_US/3M-Sustainability/Global/Environment/GoalsProgress/ 
In that day, the Technology Assessment Think Tanks were among the initiating organisations. These contributed to the further development and dissemination of this body of thought in the business community. Thanks to their societal position as advisers of the legislative branch, they were able to work simultaneously on new solutions together with a variety of different actors. This frequently took place in collaboration with incumbent politicians, scientists, entrepreneurs and a wide range of relevant stakeholders. It was this model that raised the debate on the environment, the economy and production processes to a different level and initiated further concept development by means of pioneering demonstration projects.

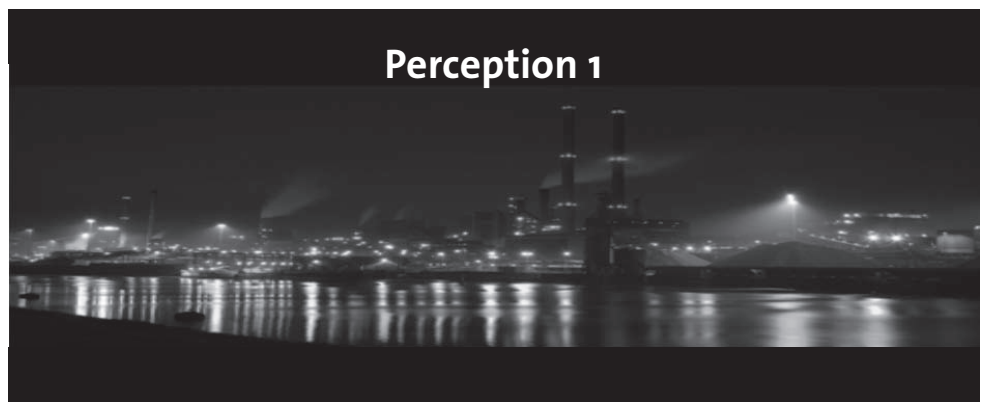

By doing this, these technology assessment think tanks moved the way the business community was dealing with environmental issues: these were brought from the outside to the inside of the company and its operations. The result was a change from being a mainly external affair for companies to a primary, internal issue that also needed to be tackled internally. This was done with the help of examples from leading companies, such as the company mentioned earlier, $3 \mathrm{M}$.

In the USA that Technology Assessment think tank was the Office of Technology Assessment (OTA) which was 'duplicated' in the Netherlands with the Nederlandse Organisatie voor TA (NOTA, later renamed Rathenau Instituut). ${ }^{37}$ Similar technology assessment think tanks in other European countries also started to dismantle the concept that the contribution made by companies to sustainable development was by definition a cost-increasing factor and consequently bad for one's competitive position.

37 Nederlandse Organisatie voor Technologisch Aspectenonderzoek (NOTA), Aanbevelingen voor een preventief milieubeleid van de overheid, NOTA Report to the Netherlands Parliament, SDU, The Hague, the Netherlands, 1991. 
The essence of that new approach consists of introducing an approach to prevent waste and emissions from being generated in production processes in the first place. First and foremost this approach aimed to control emissions by taking two measures: reduction at source and internal reuse. Teams were set up to make a step-by-step analysis of existing production processes to achieve this. Options to reduce the quantity and degree of toxicity of waste and emissions were searched for. A wide variety of organisations developed toolboxes ${ }^{38}$ and conducted demonstration projects 39 in dozens of businesses in various sectors. Better process management, the use of substitute raw materials and introducing already existing cleaner technology evidently does achieve results.

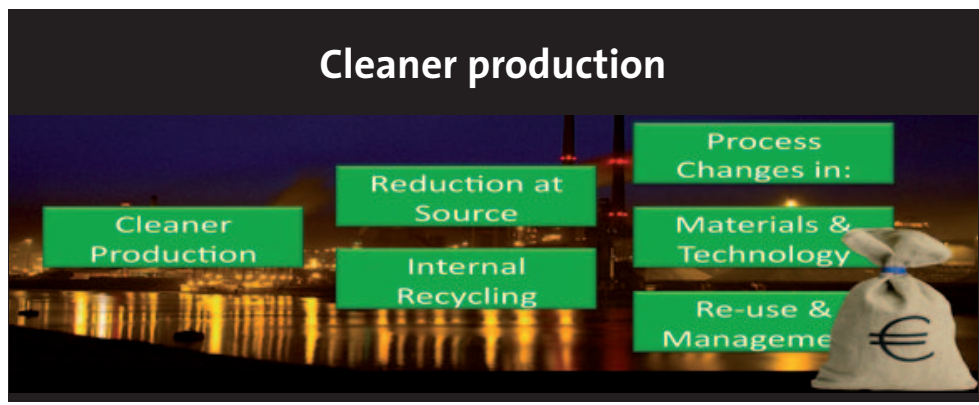

The results achieved brought about a substantial reduction in the amount of waste and emissions and/or greatly reduced the level of toxicity in the companies concerned. This demonstrated that preventing and reducing waste and emissions in corporate production processes can be done cost effectively.

38 US Environmental Protection Agency, Waste Minimization Opportunity Assessment Manual, US EPA, Cincinnati, Ohio, USA, 1988.

Hoo, S.C. de, Brezet, H., Crul, M., Dieleman, H., Handleiding voor Preventie van Afval en Emissies, SDU Uitgeverij, The Hague, the Netherlands, 1990.

Hoo, S.C. de, Brezet, H., Crul, M., Dieleman, H., Prepare: Manual and Experiences, SDU, The Hague, the Netherlands, 1991.

39 Prevention Programmes such as:

- NOTA, Project Industriële Processen met Afvalpreventie (PRISMA), The Hague, the Netherlands, 1989 -1992.

- Eureka Euroenviron, Preventive Environmental Protection Approaches in Europe (Prepare Programme under The Green Umbrella of Eureka Euroenviron), EU, Brussels, Belgium, since 1991. See for example various cleaner production publications of the United Nations Environment Program. 
In many cases there is even an attractive return on investment (ROI) to be had from taking preventive measures. In other words, it is all about interesting economic production process improvements. The environmental load from certain waste flows can be reduced up to a factor of $\mathbf{2}$ and occasionally even up to a factor of 3 to 4 . Once that improvement process gets into stride, then the process can be restarted over and over again and will lead to further improvements. This has been verified time and again in hundreds of demonstration projects.

There are apparently very few fundamental differences in the outcomes and results of these demonstration projects between the different sectors of industry in industrialised and newly industrialising countries (OECS and BRIC). The results in developing countries appear to be comparable with results achieved elsewhere. Many improvements that can be implemented quickly are those concerning the organisation of production processes. If it is a matter of technological improvements, then work is carried out with technology used elsewhere or with technology that is ready for application. However, results that can be attributed to product improvements remain few and far between.

International programmes welcome Pollution Prevention with open arms and provide widely documented results. After the first successes, trendsetting international programmes are also being started up in the Industry and Environment Programme of UNEP under the name of Cleaner Production, as well as in a programme of the United Nations Industrial Development Organisation (UNIDO) and the World Bank. Projects in dozens of developing countries have been documented since 1990.40 The European Innovation programme EUREKA/EuroEnviron has been starting up this type of project since 1991. The World Business Council for Sustainable Development (WBCSD) also welcomes and promotes a similar approach to pollution prevention under the name of Eco-efficiency. This approach is promoted among and by its members: a group of more than 200 multinationals.

40 See for example various cleaner production publications of the United Nations Environment Program, Industry and Environment Office, Cleaner Production Unit (since 1990), Paris, France. For an analysis that includes the differences between companies in size, branches and countries, see also:

Berkel, C.W.M. van, Cleaner Production in Practice, Methodology development for environmental improvement of industrial production and evaluation of practical experiences, IVAM Environmental Research, University of Amsterdam, Amsterdam, the Netherlands, 1996. 
The WBCSD has also documented these projects in a variety of different sectors since 1992, ${ }^{41}$ for instance by publishing examples and overviews. ${ }^{42}$

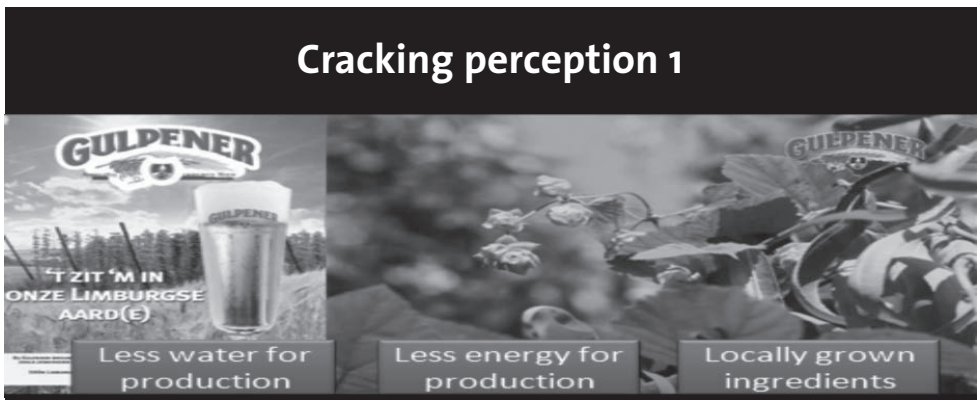

From a perspective of our times, this strategy focuses so logically on production process improvements, but in the early nineties it completely turned the then prevailing practice in environmental regulation, environmental corporate strategy and environmental investments upside down. ${ }^{43}$ Whether called 'From Pollution to Prevention'44 or 'Pollution Prevention Pays' 45 the path has been taken towards a different approach in perceptions on and the implementation of sustainable development in the business community. Its wide-scale introduction in the business community is strongly encouraged in the Netherlands and other OECD countries. In general however it has failed to penetrate deeply enough into the companies involved and has mainly remained limited to the proactive (often larger) companies.

This by no means eliminates the fact that on the basis of the results, the conclusion can be drawn that over the past two decades a preventionspecific approach has been developed for production processes which can be widely used in the business community. This approach leads to a more sustainable performance in production processes and can serve as a start for wider introduction of corporate social responsibility within a company.

${ }_{41}$ See for example various eco-efficiency publications of the World Business Council for Sustainable Development (since 1992), Geneva, Switzerland.

42 Holliday, C.O. Jr., Schmidheiny, S. and Watts, P., Walking the Talk: The Business Case for Sustainable Development, Greenleaf Publishing, Sheffield, UK, 2002.

43 NOTA Report to the Netherlands Parliament, Aanbevelingen voor een preventief milieubeleid van de overheid, SDU, The Hague, the Netherlands, 1991.

44 Congress of the United States, Office of Technology Assessment, From Pollution to Prevention, $a$ progress report on waste reduction, Washington, DC, U.S. Government Printing Office, USA, 1987.

45 For one of the founding fathers of Pollution Prevention Pays (PPP) see Huisingh, D. and Bailey, V., Making Pollution Prevention Pay: ecology with economy as policy, Pergamon Press, New York, USA, 1982. 
The extent of the results achieved can have an order of magnitude of a reduction in environmental load by a factor of 2 or more. The improvements that have been realised do not push up production costs, even often have an attractive return, and are not a threat to competition.

\section{Perception 1 has been cracked!}

\subsection{Perception 2: Sustainable product development will become too complex, have an adverse effect on product quality and product design and will lead to more expensive products}

The product-oriented approach was started at the beginning of the 1990s, leaving a gap of several years between that approach and the approach geared towards the production process discussed above. Its inception was partly in response to the limitations of that production process approach. The participating businesses virtually excluded the researchers and advisers concerned from access to the domain of their products and services. In effect, design and performance relevant to sustainable products remains to be a virtually closed area for these researchers and advisers. When viewed from the perspective of the process integrated approach, the number of options for direct substantial product improvements continues to be very few. It became clear that a different approach is needed to get sustainable product development going in companies. In those days the prevailing perception stood in the way of implementing corporate social responsibility in this part of the core business process. The persistent perception about sustainable products in the business community that must be eliminated is:

Sustainable product development will become too complex, have an adverse effect on product quality and product design and will lead to more expensive products.

The beginning: Cracking this perception about sustainable product development and products I feel is the second essential step to bringing corporate social responsibility into a company's core activities. After all, it concerns intervening in the company's heart and nerve centre, its product development process and innovation process. Dismantling this perception takes a similar route as for the process-integrated approach: develop the method, test it in demonstration projects in leading companies, communicate the results, scale it up to more extensive 
programmes, etc. First, the environmental and economic dimensions of corporate social responsibility are dealt with, at a later stage it includes also the social dimension.

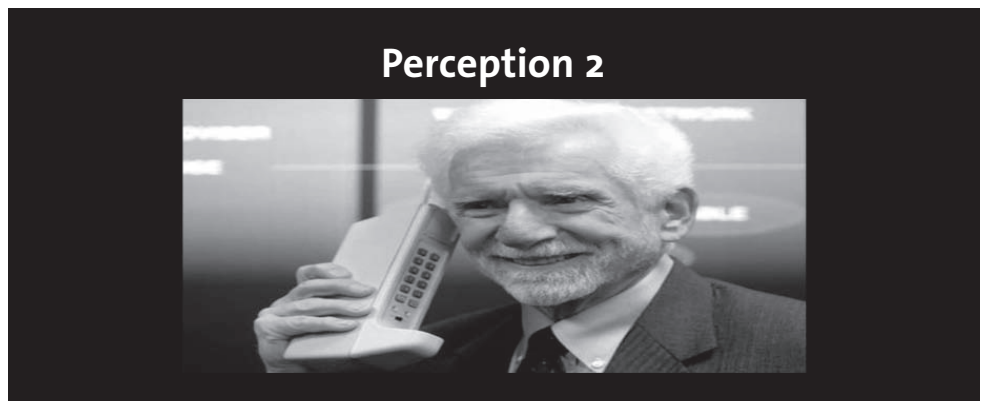

Initiating organisations are again predominantly the front running companies themselves. The technology assessment think tanks referred to above play a role in improving the methodology and widening its utilisation in the business community. The support given by governments and the knowledge infrastructure has from the very beginning been wider than when the process-oriented programmes were first launched. In this approach, which is geared towards sustainable product development, the Netherlands - at that time - was at the leading edge of international developments. Similar developments also take place in the international perspective and terms are used such as 'green products by design' 46 or 'eco-design', a term which is also frequently used in the Netherlands. ${ }^{47}$ An enormous stimulus in this respect was a collaboration programme coordinated by NOTA called PROMISE (Product Development with the Environment as Innovation Strategy) that ran from 1990 to $1994 .{ }^{48}$ Several ministries, knowledge infrastructure organisations, consultancies and businesses were collectively involved in this programme.

46 Congress of the United States, Office of Technology Assessment, Green Products by Design, choices for a cleaner environment, Washington, DC, U.S. Government Printing Office, USA, 1992.

47 Rielle, H. te, Zweers, A. et al, Eco-design: acht voorbeelden van milieugerichte productontwikkeling, TNO Productcentrum, Delft and NOTA, The Hague, the Netherlands, 1994.

48 Promise is a collaborative project coordinated by NOTA of 12 Dutch organisations, including TNO Product Centre, TNO Study Centre Technology and Policy, TU Delft Faculty of Industrial Design and The Centre for Applied Environmental Economy (TME). A further eight companies also participate: Vereniging van Bloemenveilingen, Ahrend, Olland, Focus Veilig, Leolux, Speelhout, Nedcar and Etna. 
The essence of the eco-design methodology that was developed involves successive steps that tie in with the existing product design methods. It is apparently essential to achieve a link with existing innovation processes and corporate culture as much as possible. Within these preconditions the objective is to redesign existing products or develop and design new products from a sustainable perspective. The first category of products is either in need of a facelift or has just come through a previous design phase and is basically ready for production. The second category goes through the entire path from the very beginning; from the development of product ideas into the ultimate design of the sustainable product itself. In an overall step-by-step and iterative plan, the product is assessed in terms of concept and function (including cradle to cradle approaches), efficiency and quality. Subsequently, a distinction is made between three phases. A production-phase: choose better materials, reduce materials use, optimize production and optimize packaging, distribution and logistics. A user-phase: reduce energy use and adverse effects. And the end of product-life-phase: optimize lifecycle, recycling and reuse. The materials, energy and toxicity are examined for each phase, and all potential improvement options that either give shape to the further design are looked into. 49

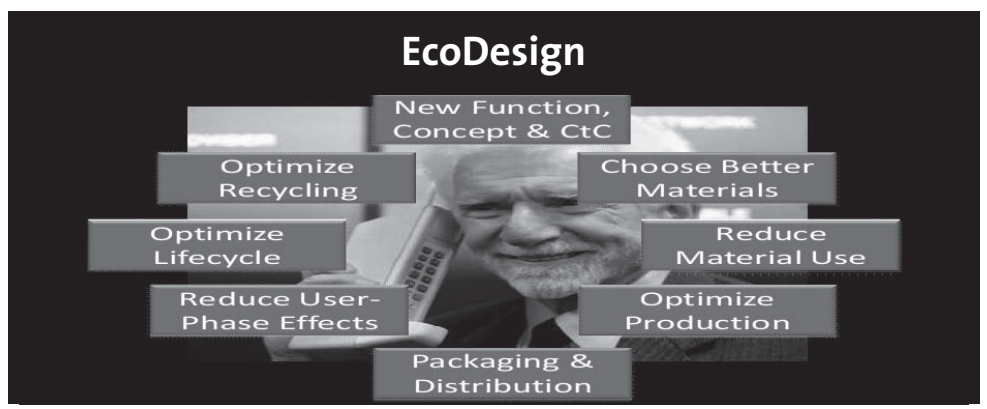

The results of the product redesign and product development projects carried out by using this methodology are quite something. A manageable and widely tested methodology has become available that leaves enough scope for customised supervision of the innovation process. This methodology has crystallised into what has been regarded

49 Hoo, S.C. de, Böttcher, H.E., Milieugerichte ontwikkeling van producten en processen, report to the Netherlands Parliament 11, Rathenau Instituut (formerly NOTA), The Hague, the Netherlands, 1994. Rielle, H. te, Zweers, A. et al, Eco-design: acht voorbeelden van milieugerichte productontwikkeling, TNO Product Centre, Delft and NOTA, The Hague, the Netherlands, 1994. Both publications summarise the essence of the methodology; for a full description of the methodology see also footnotes 19 to 25 . 
for many years now as an authoritative manual..$^{\circ}$ It has become evident that environment-oriented product development can provide a real and substantial environmental benefit and does not lead to higher costs. In most companies it seems that the cost price of products can be reduced and beneficial effects occur in the market position. Choosing a forerunner's position appears to be the most effective method over the course of time. Improvements in environmental performance for certain emissions are in the order of a factor 2 or 3 and feasible. In a few cases, product design can even completely eliminate a specific damaging effect. Probably the most promising effect of using a design for sustainability approach at that time was that corporate social responsibility loses its not so enviable position of guard or linesman in a product development process. Corporate social responsibility implemented in this manner becomes a contribution to generating innovation and a driving force for corporate development. ${ }^{51}$

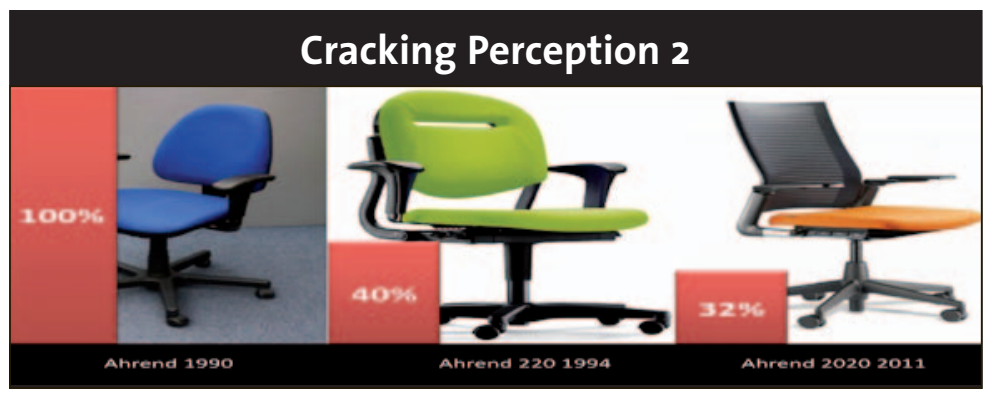

The international embedding of this product-oriented approach has also been substantial. The method has been developed further, 52 has made its way to national53 and international sustainable product development programmes. 54

50 Brezet, H. e.a., Handleiding voor milieugerichte productontwikkeling, NOTA/SDU, The Hague, the Netherlands, 1994.

51 Rielle, H. te, Zweers, A. et al., Eco-design: acht voorbeelden van milieugerichte productontwikkeling, TNO Productcentrum, Delft en NOTA, 'The Hague, the Netherlands, 1994.

52 Hemel, C.G. van, Eco-design empirically explored: Design for Environment in Dutch small and medium sized enterprises, Design for Sustainability Program publication, Delft University of Technology, Delft, the Netherlands, 1998.

53 Syntens Innovatienetwerk voor Ondernemers, Ecodesign Programma 1995- 1998 with the slogan: Een beter product én een beter milieu [A better product and a better environment]. The programme examined products in more than 600 companies. For the approach followed and the results see e.g.: - Syntens Ecodesign Milieu Innovatie Scan, 1995.

- Syntens Ecodesign Collection, 1998.

Böttcher, H.E., Hartman, L.A., Wal, H. van der, Eindrapportage Ecodesign-project, Syntens,

Amsterdam, the Netherlands, 1999.

Böttcher, H.E., Hartman, L.A. and Kooistra, S., Ecodesign Inspiratie, innoveren met product en milieu, Syntens, Amsterdam, 1999.

54 Brezet, H., et al., Ecodesign, A promising Approach to Sustainable Production and Consumption, United Nations Environment Programme, UN Publication, Paris, France, 1997. 
In association with the UNEP Cleaner Production Programme this method has been widened to include all dimensions of sustainable development. The Design for Sustainability Programme at TU Delft's55 Industrial Design Faculty played an essential and instrumental role in this process. After ten years of experience in various sectors and developing countries, a completely revised version of the methodology has been published for programmes in developing countries. ${ }^{56} \mathrm{All}$ in all, Design for Sustainability is a long-term programme - and partly because of this - is a programme that opens up new horizons. The World Business Council for Sustainable Development has integrated a comparable productoriented approach in its own approach to eco-efficiency. Time and again does sustainable product development emphasise the importance of investing in innovation, in the future, beyond the issues of the day! Its wide introduction into the business community is strongly encouraged in the Netherlands as well as in other OECD countries.

The conclusion can be drawn that more than 15 years of sustainable product development has shown that it can be implemented in companies and that the methods developed are indeed robust. A significantly positive effect has been established on the quality and design of products in the demonstration programmes, and there is evidently no price-increasing effect. The wide perception that sustainable product development would be too complex and more expensive and that it would have a negative effect on the quality and design of a product have been disproved in practice. Moreover, those results apparently occur independent of the size of a company and the nature of the sector in which the company operates. Meanwhile, some substantial modifications have been made in manuals and approach to enlarge the degree of its applicability in developing countries.

\section{Perception 2 has been cracked!}

55 Diehl, J.C., Product Innovation Knowledge Transfer for Developing Countries, towards a systematic transfer approach, Design for Sustainability Program publication no. 22, Delft University of Technology, Delft, the Netherlands, 2010.

56 Crul, M.R.M. and Diehl, J.C., Design for Sustainability, a practical approach for developing economies, UNEP DTIE, Paris, France, 2006.

Crul, M.R.M., Diehl, J.C., Lindqvist, Th., Ryan, C., Tischner, U., Vezzoli, C., Design for Sustainability, a step by step approach, UNEP DTIE, Paris, France, 2009. 


\subsection{Perception 3: Corporate social responsibility is too broad and too complex for it to be permanently embedded in a company's regular management}

Will enlightened business management create the ultimate boost for corporate social responsibility?

The efforts that were made into bringing corporate social responsibility effectively into the core of a company - into its production processes and products - were able to crack the first two perceptions. Effective methods and tools have been developed, which in practice make economic sense and result in pretty good IRR or ROI57 scores for the sustainability-geared options to invest in. It goes without saying that options for making products and processes more sustainable are occasionally defeated by other short-term lucrative investments. But this is seen less and less the higher the subject of corporate social responsibility is placed on a company's list of priorities. On the basis of the results achieved, it was expected that corporate social responsibility would automatically, and/ or without any further incentives, spread across the entire business community. However, that has not been the case!

When - after a few years - we look again at the progress made in corporate social responsibility in those companies in which demonstration projects have been executed we see the following. In a significant number of the companies involved in the demonstration projects, it was business as usual again after some time, simply as if nothing had happened. ${ }^{8}$ Apparently the underlying philosophy of the activities they had carried out could not be embedded in the company's regular management. It also became evident that the success of both approaches was disseminated to only a limited extent within a sector, within the business community or towards newly founded companies. The demonstration programmes continued to be mainly a collection of separate projects.

While the process and products approaches are apparently essential conditions to be able to develop corporate social responsibility 59 in the core of a company they are still inadequate as carriers of the process of change!

57 Internal Rate of Return (IRR) and Return On Investment (ROI)

58 Dieleman, H., De Arena van Schonere Productie, mens en organisatie tussen behoud en verandering, Uitgeverij Eburon, Delft, the Netherlands, 1999.

59 Füssler, C., Driving Eco-innovation: a breakthrough discipline for innovation and sustainability, Pitman Publishing, London, UK, 1996. 
What was missing was a continuous initiating role of regular management in the companies concerned to really embed CSR. I drew this conclusion on the basis of my own experiences in the Netherlands ${ }^{60}$ and for UNEP in China. ${ }^{61}$ My quest for such an effective management approach for corporate social responsibility started out in my job at Rabobank Group. At that time the developments in corporate practice were the main guiding principles for me. By then, a number of companies had embraced corporate social responsibility as a principle and had started to embed corporate social responsibility in the company's management. ${ }^{62}$

It became obvious that another persistent perception in the business community had to be done away with. ${ }^{63}$ The dominant view on the possible role of corporate social responsibility as a component of regular management is:

Corporate social responsibility is too broad and too complex to be permanently embedded in a company's regular management.

We come across this perception on all company levels, whether or not combined with the attitude that corporate social responsibility diverts attention too strongly from the efforts to produce adequate financial returns and fails to lead to strategic innovations. This perception must be cracked before corporate social responsibility as a component of regular management has the opportunity to grow and to lead to process and product innovations.

The actual start made on cracking this perception was initiated by front running companies. These are the proactive companies that use and gradually advance the development of corporate social responsibility by trial and error.

60 In the design and management of two large pollution prevention programmes - for the Dutch Organisation of Technology Assessment (NOTA/Rathenau Institute) - on process and product design in the Netherlands: respectively PRISMA (1989-1993) and PROMISE (1992 - 1995).

61 In the design and management of various programmes on cleaner production for UNEP Industry and Environment Office in Paris, for example The Cleaner Production in China Programme (1992 -1997).

62 Hoo, S.C. de, and Clarke, R., Sustainability, choices and challenges for future development, Rabobank International, Utrecht, the Netherlands, 1998. Report drawn up to celebrate the 10oth anniversary of Rabobank and used as the background for a two day conference in Figi, Zeist.

Hoo, S.C. de, Clarke, R. et al, Sustainability, choices and challenges for future development: The Chinese Experience, Rabobank International, Utrecht/Shanghai, the Netherlands, 1998. Report made for the conference to celebrate the Opening of Rabobank Shanghai.

63 See also e.g. Why nobody likes sustainable development, the business connection, in: Holliday, C.O. Jr., Schmidheiny, S. and Watts, P., Walking the Talk: The Business Case for Sustainable Development, World Business Council for Sustainable Development, Greenleaf Publishing, Sheffield, UK, 2002. 
The idea is that by working on the basis of mission, strategy, policy and management, corporate social responsibility can become embedded in a company's core business.

Some stimulating international developments made around the change of the century were of huge importance to the efforts to bring corporate social responsibility into the regular management of companies. These developments are rooted in the increasing pressures society exerts on the business community to assume responsibility and make a contribution towards sustainable development.

Firstly, the starting signal for the Dow Jones Sustainability Index (DJSI, launched in 1999) ${ }^{64}$ on the basis of research conducted by Sustainable Asset Management (founded in 1995). ${ }^{65}$ Secondly, the first Global Reporting Guidelines of GRI (launched in 2000) ${ }^{66}$ were formulated and tested in draft form after consultations were held with numerous stakeholders worldwide. Thirdly, the Global Compact (GC, launched in 2000) ${ }^{67}$ was started up, which was strongly supported by the knowledge and experience obtained in the World Business Council for Sustainable Development (WBCSD). All these developments bring CSR into the boardroom as a strategic, core business issue.

64 The Dow Jones Sustainability Index is the first ever family of global sustainability benchmarks. The Dow Jones Sustainability Indexes (DJSI) are identifying sustainability leaders across all industries. The DJSI enables investors to integrate sustainability considerations into their portfolios while providing an effective engagement platform for encouraging companies to adopt sustainable best practices.

65 Sustainable Asset Management (SAM) was founded in 1995 and based in Zürich, Switzerland. SAM started as an independent asset management company specialised in sustainable investments. Sustainable Asset Management has an independent Research group which is one of the foremost in the field of sustainability. In 1999 SAM, together with the Dow Jones Company, launched the Dow Jones Sustainability Index (DJSI). In 2006 SAM became part of Robeco, a subsidiary of Rabobank. SAM is presented with various awards for investment products, research and specific sustainability theme financial products (Clean Tech, Climate, Water, etc.)

66 The Global Reporting Initiative (GRI) strives for a sustainable global economy in which organisations manage their economic, environmental, social and governance performance and impacts. GRI strives to achieve transparent reporting about these responsibilities and performance. Therefore, GRI wishes to make sustainability reporting standard practice by providing guidance and support to organisations. GRI is a network-based organisation and its reporting framework is being developed through a consensus-seeking, multi-stakeholder process. Participants are drawn from global business, civil society, labour, academic and professional institutions. Global Reporting Initiative (GRI), Global Sustainability Reporting Guidelines, 2000, 2002 and 2008.

${ }_{67}$ The Global Compact enlists corporate engagement in promoting ten principles drawn from the Universal Declaration of Human Rights, the Declaration of Fundamental Principles and Rights at Work of the International Labour Organisation (ILO) and from the RIO Declaration on Environment and Development. These represent the aspirations of the entire international community. 


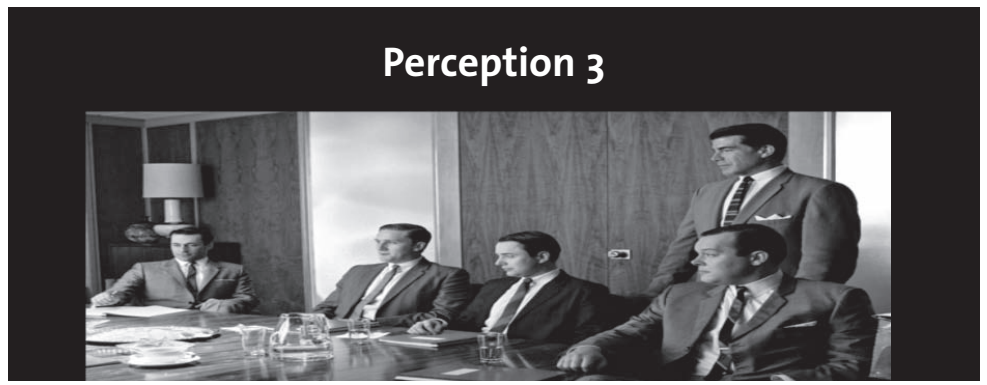

The first development (DJSI) is a significant step in the process to embed corporate social responsibility in the financial services sector, which provides an extra dimension to the need for CSR in the boardrooms of (listed) companies. The second development (GRI) resulted from the work carried out by a multi-stakeholder organisation ${ }^{68}$ which presses for corporate social responsibility and transparent reporting on progress in performance. This organisation laid the basis for an internationally accepted set of guidelines that were developed further by GRI. The third development (GC) wishes to promote corporate social responsibility globally in a joint programme involving companies, governments and NGOs. Over the past decade, these three developments have given an enormous boost to the development of corporate social responsibility and laid the basis for further improvements in its management. This was done by linking corporate social responsibility performance to: financial markets and indexes (DJSI), reporting, management and management information systems (GRI) and a continuous improvement process of the management approach based on practices of a few thousand companies (GC).

After a few years of experience, Global Compact published an excellent guide to managing corporate social responsibility in companies, produced by representatives of many companies involved. This guide, 'Raising the Bar'69 is based on the 10 GC principles that must be observed. These 10 principles are subsequently linked to various internationally observed codes and guidelines for corporate social responsibility.

68 Ceres is a US based, non-profit, network of investors, environment organisations and other public interest groups. Its core mission is to integrate sustainability into capital markets and therefore works with companies and investors to address sustainability challenges. Ceres is an influential player in corporate governance and the founder of the Global Reporting Initiative (GRI) which now is the de facto international standard for corporate reporting on environmental, social and economic performance.

69 Füssler, C., Cramer, A., Vegt, S. van der, Raising the Bar, creating value with the UN Global Compact, Greenleaf Publishing, Sheffield, UK, 2004 
This is used to establish company-specific corporate social responsibility content, and following the quality management approach it is then connected up with the overall corporate management system. The guide sets out a practicable step-by-step approach for incorporating corporate social responsibility in regular management cycles. The developments in managing corporate social responsibility in proactive companies must be seen against this background. The 'turbo-charge' on embedding CSR was thus switched on for this small group of leading companies around the turn of the century.

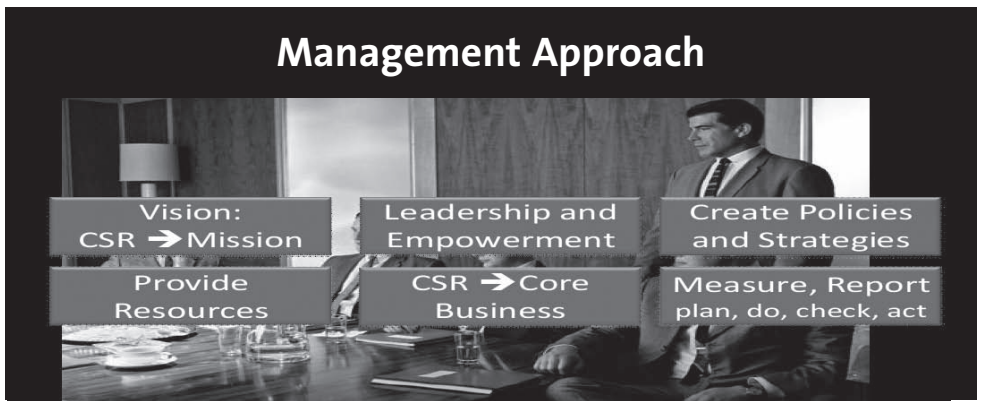

Around the turn of the century several unique programmes were started up in the Dutch context also. Programmes in which the setting up and management of corporate social responsibility in several Dutch companies was encouraged, evaluated and documented. $7^{0}$ The initial focus was on starting and expanding corporate social responsibility in the company itself, then in a second programme the focus was on managing corporate social responsibility in the Netherlands and in foreign activities/subsidiaries. Additionally, a National Research Programme on Corporate Social Responsibility was developed at the assignment of the Netherlands Ministry of Economic Affairs. Practices were linked up to theoretical insights in this programme and the 'state of the art' comes into view.7' In all these practice-oriented projects, Cramer's organisational and substantive qualities to run complex programmes become quite visible. The produced overview publications illustrate the development in practice and theory and zoom

70 Nationaal Initiatief Duurzame Ontwikkeling (NIDO), later taken over by MVO Nederland, organises these programmes under the title of Van Financieel naar Duurzaam Rendement, 1999 - 2002. Cramer, J., Ondernemen met Hoofd en Hart, Duurzaam Ondernemen: praktijkervaringen, Van Gorcum, Assen, the Netherlands, 2002.

71 Nationaal Onderzoeksprogramma Maatschappelijk Verantwoord Ondernemen (2003-2004) was coordinated by the Ministry of Economic Affairs, The Hague, the Netherlands. 
in on the management of corporate social responsibility. ${ }^{72}$ Cramer's four orations,73 spanning a period of more than 15 years (from 1991 to 2006), can also be read as documents of historical interest on the search for effective implementation of corporate social responsibility.

\section{Results}

I have racked my brain as to how improving the management of corporate social responsibility can be illustrated without falling into a neverending series of examples in specific situations. I have therefore chosen to work with the evaluation studies of corporate social responsibility annual reports. Corporate social responsibility annual reports, according to the companies that publish them, are first and foremost aimed at clearly communicating their corporate social responsibility performance to stakeholders. Secondly, they are intended for the purpose of being able to constantly improve the management of that performance. Of course one must also be aware of the possible 'green washing' character of those annual reports. Taking these considerations into account I did choose a type of evaluation studies known for their rigorous approach and fully transparent methodology: the series of reports on benchmarking environmental and corporate CSR annual reports from SustainAbility.

These evaluation studies were based on a publicly available methodology and provided a thorough examination of the following subjects (see next box):

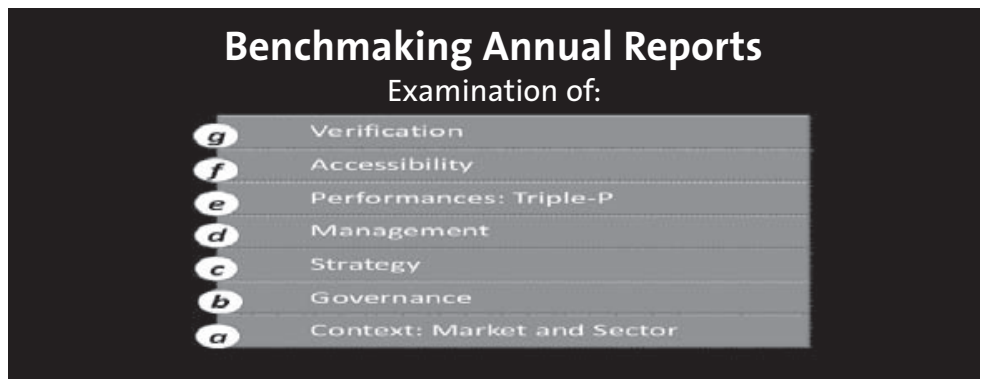

72 Cramer, J., Jacobs, M., Jonker, J., Ondernemen met MeerWaarde, een overzicht van de praktische resultaten van het Nationale Onderzoeksprogramma Maatschappelijk Verantwoord Ondernemen, Ministry of Economic Affairs, The Hague, the Netherlands, 2005.

73 Cramer, J.C., De illusie Voorbij, op weg naar een brede aanpak van de milieuproblemen, Address at the Amsterdam University, Van Arkel, Utrecht, the Netherlands, 1991.

Cramer, J.C., Milieumanagement; van "fit" naar "stretch", Address at Tilburg University, Van Arkel, Utrecht, the Netherlands, 1997.

Cramer, J.C., Duurzaam in Zaken, Oration at Erasmus University Rotterdam, Koninklijke Van Gorcum, Assen, the Netherlands, 2001.

Cramer, J.C., Duurzaam Ondernemen: van defensief naar innovatief, Address at Utrecht University, Utrecht, the Netherlands, 2006. 
Using these studies enables me to give a cautious indication of the degree to which corporate social responsibility can be managed successfully within a company; how that management is executed and to what performance it leads. The methodology used in most other evaluation studies by different parties in the market are a black box for the user for a long time now. Only in recent years has this situation undergone a slight improvement. 74

Up to the end of the 1990s, non-financial reporting in companies mainly concerned the environmental dimension. Work conducted by SustainAbility holds a special place in this category of benchmark publications. From the very first publication of these studies in 1994 they were in great demand and resulted in heated reactions from companies that found themselves mentioned in the benchmarks and ratings. 75 No wonder, because even the best of reports and their reported performance originally scored no more than a meagre six.

The first international benchmark covering the wider terrain of corporate social responsibility in that series of SustainAbility publications dates from 2000. It relates to the performance of companies in 1999 and presents a top $-50.7^{76}$ This study shows low valuations and causes heated

74 SustainAbility Ltd., Global Reporters, The Report Assessment Methodology, SustainAbility, London, UK, 2006.

Mistra and SustainAbility Ltd., Reviewing the Quality of Social Responsible Investment Research, SustainAbility, London, UK, 2004.

SustainAbility Ltd., Rating the Raters, phase one to phase four, commissioned by various listed companies, SustainAbility, London, UK, 2011.

75 SustainAbility Ltd., Company Environmental Reporting: a measure of progress of business and Industry towards sustainable development, UNEP Industry and Environment Program, Technical Report 24, Paris, France, 1994.

SustainAbility Ltd., Engaging Stakeholders, Volume 1: The Benchmark Survey and Volume 2: The Case Studies, commissioned by UNEP Industry and Environment Program, SustainAbility, London, UK, 1996. SustainAbility Ltd., The 1997 Benchmark Survey: The Third International Progress Report on Company Environmental Reporting, commissioned by UNEP Industry and Environment Program, SustainAbility, London, UK, 1997.

76 SustainAbility Ltd., The Global Reporters, first international benchmark 2000, survey of corporate sustainability reporting, commissioned by UNEP Industry and Environment Program, SustainAbility, London, UK, 2000.

SustainAbility Ltd., Trust Us, The Global Reporters 2002, survey of corporate sustainability reporting, commissioned by UNEP Industry and Environment Program, SustainAbility, London, UK, 2002. SustainAbility Ltd., Risk and Opportunity, The Global Reporters 2004, best practice in non-financial reporting, commissioned by UNEP Industry and Environment Program, SustainAbility, London, UK, 2004 SustainAbility Ltd., Tomorrow's Value, The Global Reporters 2006, survey of corporate sustainability reporting, commissioned by UNEP Industry and Environment Program, SustainAbility, London, UK, 2006. SustainAbility Ltd. and KPMG, Count me in, the readers take on sustainability reporting 2008 , commissioned by the Global Reporting Initiative (GRI), SustainAbility, London, UK, 2008. SustainAbility Ltd., KPMG and Futerra, Reporting Change, the readers and reporters survey 2010, commissioned by the Global Reporting Initiative (GRI), SustainAbility, London, UK, 2010. 
discussions with the companies that had been assessed on the rating results and the method used. In 2000, the 'Magnificent Six'77 scored about $60 \%$ of the maximum score (196). One of the components is management quality, which scores between the 50 and $60 \%$. As soon as we look at the chasers and the main peloton that score quickly drops. The average total score among the top 50 companies in 2000 was only $43 \%$. The average score of the top 50 for corporate social responsibility management quality was $46 \%$. In other words, there is much room for improvement, both in the small group of leaders as well as the followers. I do illustrate that improvement process with the table below.

Taking the successive studies into account we see an increase in overall performance, as well as in the separately measured management quality. The top ten scores in the top 50 list of corporate social responsibility leaders increase. In 2006 the number one even achieves $>80 \%$ of the total score. The same trend is observed in the scores in the separate category of management quality. Companies are capable of embedding corporate social responsibility in their company's regular management including the existing management information systems. Unfortunately, the publication of these types of studies and their top 50 list was discontinued in 2006.

Table 2: Overall performance score on CSR. Overall performance includes management quality. Sources: SustainAbility, Global Reporters Surveys in subsequent years $2000-2006$.

\begin{tabular}{|c|c|c|c|c|}
\hline \begin{tabular}{|c|c|c|} 
Year of performance \\
Position in top 50
\end{tabular} & 1999 & 2001 & 2003 & 2005 \\
\hline 1 & 61 & 61 & 71 & 80 \\
\hline 10 & 48 & 48 & 59 & 64 \\
\hline 20 & 43 & 42 & 51 & 59 \\
\hline 30 & 41 & 39 & 47 & 55 \\
\hline 50 & 36 & 36 & 43 & 51 \\
\hline 50 & 29 & 29 & 39 & 39 \\
\hline
\end{tabular}

77 The Magnificent Six in 1999 are: BAA, Novo Nordisk, Co-operative Bank, British Telecom, BP Amanco and Shell Group. 
A similar picture of increasing scores is also seen in the Transparency Index ${ }^{78}$ which is drawn up for Dutch companies at the assignment of the Netherlands Ministry of Economic Affairs, Agriculture and Innovation. The scores show an ascending line and bring attention to how thin the top layer of companies in terms of CSR performance really is. While that top layer is steadily growing it stops at a few dozen companies in the benchmark. In 2010 the score for the number one company in the Transparency Index had increased to approximately 95\%. The score of the company at number 50 was approximately $55 \%$ and number 100 scored about 30\%. Also the previously discussed rating company, SAM, shows scores in 2010 around 90\% for overall performance of the leading companies in some sectors.

Recently the Robeco Quantitative Strategies Department published longitudinal research based on SAM data and concludes the following:79 there is a positive relation between CSR and financial performance (measured in stock-returns); this positive relation becomes stronger during and after the financial crises which indicates better risk characteristics; CSR investment strategies prove positive in both, rising and dropping markets.

Figure 7: Cumulative outperformance in \% (companies analysed in yearly SAM Corporate Sustainability Assessment with $n=465$ each year) between 2001 and 2011 (the line in the middle represents the upper $20 \%$ of the CS-assessed companies (leading) and the line below represents the lowest $20 \%$ of the CS-assessed companies (laggards)

Source: Sustainable Asset Management AG, SAM White Paper, Alfa uit duurzaamheid, Zürich, Switserland, 2011.

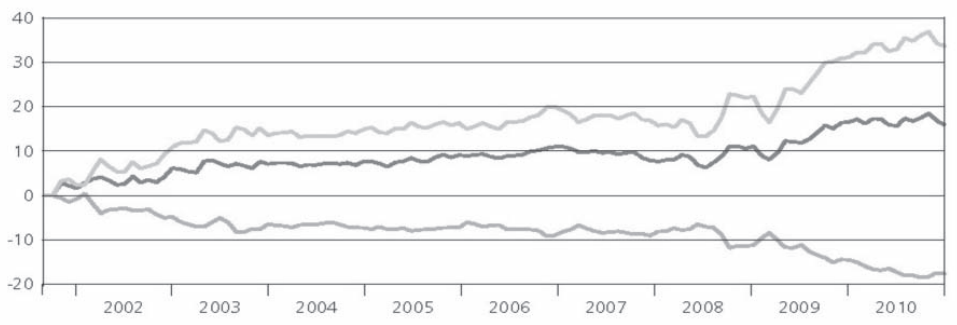

78 Netherlands Ministry of Economic Affairs, Transparantie Benchmark 2004, 2006, 2008, en 2010, The Hague, the Netherlands.

79 Sustainable Asset Management AG, SAM White Paper, Alfa uit duurzaamheid, Zürich, Switzerland, 2011. 
The explanation of the results found provides arguments related to management qualities. CSR top companies have better management characteristics with regard to: stakeholder engagement; reputation management; operational efficiency; long-term vision and last but not least a much better understanding of competitors and society at large. This fully supports the claim that front running companies master to bring CSR into their regular management practice.

I conclude that over the past decade it has become apparent that embedding corporate social responsibility in the management of companies is possible. I consider the perception that corporate social responsibility is too broad and too complex for it to be permanently embedded in a company's regular management as untenable. Regardless of the fact that for the time being this competence seems to remain in the hands of a select group of pioneering companies, I conclude that:

\section{Perception 3 has been cracked!}

I will now turn to the question why a stronger regulation framework is needed to implement CSR in the broader business community. 


\section{A plea for a stronger regulatory approach}

As a CSR manager I became strongly convinced that CSR provides a multitude of advantages to the business community on nearly every level of performance. In my view this self-interest for business would be the major engine to move CSR into the core of corporate performance. I was therefore convinced that a voluntary approach could prove to be sufficient to make CSR the predominant way to do business and become the standard for the early 21st century. Until the mid nineties I even strongly defended the approach to reduce regulation and not interfere in the implementation process of CSR. At that time my colleague Michael Faure took the opposite stance and our debate ended more or less in a stalemate. Recently, however, he reminded me elegantly about this sin I had committed in my younger years and at last he earned his bottle of Champagne. Fifteen years later, my experience and knowledge about the actual process of implementing CSR in the business community did guide me to make the following plea for stronger regulatory approaches, if delicately designed.

\section{Reasons for a stronger regulatory approach, because:}

1. CSR-concept still contradicts the traditional business paradigm

2. Voluntary CSR creates too little spin-off

3. Voluntary CSR proves extremely vulnerable during embedding

4. External pressure seems a prerequisite

\section{Some key reasons for my plea for a stronger regulatory approach}

CSR as a concept still contradicts the traditional business paradigm. CSR managers point out that in pursuit of CSR it is the existing economic paradigm in most companies - almost perceived as invincible - that substantively reduces the pace of change in the direction pursued. They refer to the dominant paradigm in which the relationship of the economy with society and the environment is outlined and states that:

.... the traditional business-view places the environmental and social dimensions as separate entities outside economic considerations and gives them a smaller relative importance. Conventional business 
intuition sees priorities in these dimensions as competing. This dominant traditional business view is hard to change and its continuous presence slows down CSR-induced changes and reverses progress made in CSRinduced organisational change and performance, with an invisible hand .... ${ }^{80}$

CSR managers proclaim that a more accurate frame of reference would reverse this perspective and acknowledge that the global economy functions within global society, which in turn functions within the global environment that is necessary for life as we know it. There is a need to acknowledge this view in order to be able to change the overall strategy, functioning and direction of corporations and will support their performance. $^{81}$

Voluntary CSR creates too little spin-off by its own merit I have shown that in front running companies CSR has moved from the corporate periphery to core business and occasionally it even became an essential part of corporate vision, strategy and management. However, it appears that this development reflects events at the very front line of CSR developments. The spin-off of CSR into the business community as a whole remains limited and far below expectations. Existing levels of voluntariness makes this implementation process stop at the border of some front running companies. The state of the art in the CSR concept and approaches is robust enough to be imposed more forcefully on the broader business community.

Voluntary CSR proves vulnerable during the process of embedment The implementation of current, voluntary CSR approaches in organisations can be described as a dynamic and continuous process that includes organisational stages and cultural phases. ${ }^{82}$ Stages go from active resistance to CSR until a situation is achieved in which CSR is fully embedded. CSR is seen as fully embedded as soon as it becomes a part of business as usual and a company's regular management. Through this process, CSR can indeed progressively integrate in a company

8o Paraphrased and based upon Willard, B., The Sustainability Advantage: Seven business case benefits of a triple bottom line. New Society Publishers, Gabriola Island, Canada, 2002.

81 Porter, M.E. and Kramer, M.R., Creating Shared Value: how to reinvent capitalism and unleash a wave of innovation and growth. Harvard Business Review, January-February 2011

82 Maon, M., Lindgrin, A. and Swaen, V., Organizational Stages and Cultural Phases: a critical review and a consolidative model of corporate social responsibility development, International Journal of Management Reviews, 2010. This consolidative model distinguishes 3 phases and 7 stages of CSR development in organisations. 
until it is fully embedded. But the actual development in companies frequently shows that CSR implementation processes, before CSR is fully embedded, are reversed and consequently develop all the way back to earlier stages. This shows a kind of vulnerability in which the levels of CSR that have been reached today remain very fragile, even within front running companies which should be avoided.

External pressure is a prerequisite to successful CSR implementation processes

CSR managers reveal that they encounter persistent resistance to CSR implementation at various levels in their companies. According to their views, the creation and implementation of current, predominant voluntary CSR is therefore highly dependent on the personal characteristics of its proponents. This also leads to a management approach in which people are tempted, rather than being pushed to contribute to CSR. Progress depends largely on distinctive cultural features in their organisations as well as on the degree of support from internal stakeholders, clients and external stakeholders. In relation to this they state that improving CSR performance becomes 'easier' as soon as levels of stakeholder pressure rise and the results of external verification, rating and benchmarking start to be converted into a continuous internal pressure to proceed. Many organisations start their CSR journey by embracing respected external guidelines (OECD, Global Compact, GRI, ISO 26000, etc.) for CSR practices from this perspective and translate the provided CSR guidance into specific characteristics for organisations. These guidelines are in some cases already regarded as 'soft law'.

Because of these reasons, the development and design of a stronger regulatory framework is needed and in order to be successful it should incorporate a mixed package of changes in corporate governance, corporate law, regulation and economic instruments.

Some guiding principles in the development of a stronger regulatory approach

In my view we can use the patterns shown in current practices of CSR implementation to formulate some guiding principles. If we change the perspective from 'how to manage or embed CSR as a voluntary approach' to a perspective in which also a 'creative design of corporate law, regulation and economic instruments could be provided to speed up CSR implementation' the following guiding principles should be acknowledged. 


\section{Guidance for the development of a stronger regulatory approach}

1. Create alignment in CSR interests on various levels in society

2. Stimulate stakeholder involvement and CSR induced innovations

3. Anticipate vast organizational changes induced by CSR

4. Stimulate full embedment of CSR providing lasting results, motivation and leadership.

Create alignment in CSR interests on various levels

A study of the success of current CSR programmes based on literature and interviews with CSR managers, policy-makers and experts ${ }^{83}$ indicates that CSR projects or programmes can only be successful if CSR managers take simultaneous action on three different organisational levels. These levels are: the level of society, corporate level and programme level. This substantial, intrinsic complexity occurs because the dominant stakeholder interests differ on each level, the relevant decision makers differ, and the decision makers have different priorities and alternatives to choose from. As soon as differences in CSR performance and interests between these levels exist, a yo-yo effect in CSR progress occurs. Therefore managers of CSR programmes must align these broader stakeholder interests on each of these levels. Failing to achieve this on these three levels generally results in the failure of a specific CSR programme.

\section{Stimulate stakeholder involvement and CSR induced innovations}

CSR managers are convinced that their central aim in the implementation process of CSR is to create innovations and the new business that originates from it. The backbone of CSR implementation in companies is innovation. Therefore the role of stakeholders also changes and will assume the character of 'a broader, society based guidance' for innovation. In order to be able to reach this, a company should be more open to its key stakeholders and to developing longer lasting relations with these stakeholders. The more innovation is generated on the basis of CSR implementation, the more CSR will be embraced and the more it will

83 Hoo, S.C. de, Groot, T.L.C.M., Jonge, F.H. de, Dommerholt, E. and Bunders, J.G.F., Duurzaam ondernemen: een onderzoek naar effectieve stimulering, verbreding en verankering, Athena Institute, Vrije Universiteit, Amsterdam, the Netherlands, 2010. This study is based on interviews and CSR literature. The interviews with CSR managers were held between October 2009 and February 2010. 
become part of the core business and processes. CSR-induced innovation proves to be mainly a result of longer lasting CSR programmes. ${ }^{84}$

The CSR based innovations could take place on different levels. These could become visible in the company's paradigm or its business models. It could also take place in the positioning of the company within its broader context or in the approach of markets: new or existing. Innovation could also take place in the essential administrative and production processes. For example it could take place in the incentive policies (where bonuses could become CSR dependent) or in the intensity and purpose of stakeholder engagement. In the longer run, next levels of innovation also become visible. ${ }^{85} 86$

CSR implementation processes provide innovations and alter the organisation, its business models and its performance. It has the character of a second order change. ${ }^{87}$ Acknowledgement of the key role that innovation and stakeholder involvement play in the CSR implementation process should therefore play a key role in all efforts to accelerate the process.

\section{Anticipate vast organisational changes induced by CSR}

CSR managers consider various changes necessary in order to give CSR a substantial position in their organisation. In their view, CSR should co-create the organisation's mission, strategy, policies, production processes, products, innovation approaches, training, education, management and management information systems. CSR managers refer to these CSR induced changes as 'a vast organisational change' affecting most corporate structures. During implementation of these changes, slowly but steadily a more CSR-friendly corporate culture and an improved CSR-based performance is created. However beyond the general characteristics of CSR there is no such thing as a single CSR approach for all. CSR should be thoroughly translated into clear terms and concepts as well as specific features for each sector and company to capture risks and opportunities, to become part of core business and to deliver positive results.

84 Bessant, J.R. and Tidd, J., Innovation and Entrepreneurship, John Wiley and Sons Ltd, Chichester, UK, 2007.

85 Nidumolo, R., Prahalad, C.K. and Rangaswami, M.R., Why sustainability is now the key driver for innovation, Harvard Business Review, September 2009.

86 Porter, M.E. and Kramer, M.R., Creating Shared Value: how to reinvent capitalism and unleash a wave of innovation and growth. Harvard Business Review, January-February 2011.

87 Anderson, R., Confessions of a Radical Industrialist, Random House Business Books, London, UK, 2009. 
Stimulate full embedment of CSR that provides lasting results, motivation and leadership

CSR managers are convinced about the fundamental character of CSR implementation processes and argue that this is why these changes are mostly stimulated by strong leadership from CEOs and senior management. But managers change jobs frequently and CEOs do not have an unlimited lifespan either. That is why CSR managers argue that even moderate changes in senior management layers could take the level of CSR performance in a company back to square one. The same could result from a takeover, a merger or an acquisition in which new visions and missions are formulated. Therefore one of the downsides of the strong dependency of personal motivation and leadership in the implementation of CSR is that levels of CSR performance are uncertain as long as CSR is not properly embedded in organisational structures. As said earlier, CSR should co-create an organisation's mission, strategy, policies, production processes, products, innovation approaches, training, education, management and management information systems. It should find its way into the core business of each company. ${ }^{88}$ Properly embedding CSR is the key.

Because of these reasons a stronger regulatory framework must be developed and the guiding principles must be taken into account while doing so. ICGI will be a solid research platform to help design an effective mix of instruments in order to speed up CSR implementation in corporations.

88 Füssler, C., Cramer, A. and Van der Vegt, S., Raising the Bar: Creating value with the UN Global Compact, Greenleaf Publishing, Sheffield, UK, 2004.

Nidumolo, R., Prahalad, C.K. and Rangaswami, M.R., Why sustainability is now the key driver for innovation, Harvard Business Review, September 2009. 


\section{The significance of the foregoing for my work at ICGI}

I have claimed that sustainable development and its conversion into corporate social responsibility has gradually taken shape over the past decades. Today, both of these concepts are considered robust enough to play a key role in future business management. These two concepts, sustainable development and CSR, have also gained wider support in society. The latter is quite perceptible, among other things thanks to the many organisations that draw up codes and guidelines for it. Nowadays, these cover the entire spectrum of multinational companies, large and small companies, including start-ups in all sectors of the economy.

I also stated that over the past decade, corporate governance has become an indispensable fourth dimension of CSR. Adjustments in governance are considered essential to successfully implement CSR in companies. I then pointed out that over the years different perceptions had to be cracked; persistent perceptions that stand in the way of implementing CSR. These perceptions chiefly concern assumptions about the too low a level of the actual applicability of CSR for bringing it into a company's core processes. These core processes concern the development and redesign of; production processes, products or services from the perspective of CSR. Despite the fact that these perceptions have been adequately cracked, it has still not led to the anticipated dissemination of CSR in the business community. CSR continues to be a world of somewhat independent demonstration programmes and projects.

The implementation of CSR in regular company management and the constant stimulation that stems from it is lacking. This was apparently also connected with a persistent perception that boils down to CSR being far too distanced from regular management. Only in recent years has a leading group of companies shown the number of possibilities available to fully embed CSR in regular management. The bonus that this has in store for a company is that after a few years, unexpected and substantial innovations occur. Gradual and radical innovations do arise in business cases, products, services, production processes and all support activities.

But despite all this it still appears that CSR is hardly being disseminated in the business community at large. CSR still comes to a halt at the 
gates of a small group of front runner companies, and the peloton of companies is failing to gain ground. Because of this reason I made a plea for a stronger regulatory framework to stimulate CSR implementation in the business community. Based upon the experience of CSR managers in companies I also provided some additional reasons and guiding principles. These should be taken into account in the design of the effective mix of instruments. ICGI will be a solid research platform to do so. In cooperation with my colleagues, students and PhD candidates I will concentrate on:

- CSR management, performance, innovation and business cases

- The research into a mix of instruments to accelerate implementation of CSR in the business community.

- The research into the potential role of corporate law, corporate governance and economic instruments in this mix in general with a special attention to:

- International product chains

- Procurement policies.

The reasons and guiding principles I have mentioned for a corporate social responsibility incentives policy have a multidisciplinary character. At ICGI we hold the opinion that this issue should not be shifted from the one discipline to the other. In my mind, ICGI will be a place where representatives of science, societal organisations, politics and the business community meet up. Their collective knowledge will be used to develop the new solutions to remedy the CSR diffusion problem. ICGI should function as a Corporate Sustainable Factory. A policy workshop in which we will approach the aforementioned problem with methodologies used in open innovation processes. Intensive collaboration and synergy is actively sought: both within our own university and outside the university's walls.

How far the path we have already taken will prove to be a success will be one of the subjects that will be dealt with during the second symposium ICGI will organise. I will be pleased to tell you more at that symposium and I am looking forward to my work in the upcoming period. 


\section{Word of thanks}

This brings me to the end of my inaugural address. ${ }^{89}$ I would now like to express my gratitude to my colleagues Kid Schwarz and Bas Steins Bisschop for their confidence and their support in the nomination process of me as professor holding an endowed chair at their new institute. Corporate Social Responsibility and Innovation has become one of the disciplines at the Maastricht University Institute for Corporate Law, Governance and Innovation Policies, known as the ICGI. Thanks to the Executive Board and the Board of the Faculty of Law, ICGI has finally arrived. We have a mission ahead of us in which we will make a collective attempt to give a new impetus to the implementation of corporate social responsibility.

Special thanks go to Kid Schwarz who, both as a friend and colleague, is an absolute delight to know and work with. We are meanwhile giving supervision to several 'external' doctoral candidates. These are doctoral candidates who work for a company and have the ambition to obtain their doctorate on CSR research based on a multidisciplinary approach. My colleagues Michael Faure, Eric Loos, Kid Schwarz and myself have moved heaven and earth over the past year to launch a new research magazine simply because it's such fun to do and is so very necessary. You will soon hear all about that!

In one and the same breath I would also like to thank my other colleagues associated with ICGI. A thank you goes to Christine van Basten, my help and stay as well as my manager. A thank you goes also to Mieke Olaerts, Jos Hamers and all other colleagues from ICGI which have from the very beginning provided me with a place in their office and also in their work. They are excellent colleagues. Meanwhile we concentrate on collaborative papers, articles and research proposals. In short some progress is being made.

I also wish to express my appreciation of my former colleagues at NOTA/ Rathenau Institute, UNEP and Rabobank, as well as my colleagues at VU University Amsterdam. Many of them have done exceptional work in the field of corporate social responsibility. A special place in the

89 I am greatly indebted to Harriët Böttcher, René Hartman, Henk Smit, Egbert Dommerholt, Chris Miles, Wim Kuppen, Kid Schwarz, Jan Eijsbouts, Michael Faure and Christine van Basten-Boddin for being so patient with me and also for their comments on a draft version of this inaugural address. 
most recent history is taken up by colleagues like Bart Jan Krouwel, René Hartman, Henk Smit and Egbert Dommerholt. Egbert, as my first doctoral candidate at VU University Amsterdam. René Hartman, who always seems to have several solutions on tap, even before the problem emerges. Henk Smit, that pillar of strength and intrepid go-getter, and finally, Bart Jan Krouwel, the extrovert battering-ram who ultimately gets everything moving and then guides it in the right direction.

In addition to those few people I have mentioned there are many others who are so important to me that I prefer not to mention any names at all lest I leave someone out. Many of them are here and they know what they mean to me. I do mention Roel, Nancy, Thomas and Lucas, who are in the hors catégorie because without them this adventure could not have taken place at all.

Last but not least my wife Harriët and son Bart, two crucial stars of my life!! What a luxury as long as you keep on shining.

Let me move on to Jan Eijsbouts. Jan is my highly experienced CSR colleague at ICGI. Together with him I teach the course corporate social responsibility and law. After listening to my narrative today you will have understood that it is me who contributes corporate social responsibility and innovation and Jan Eijsbouts who contributes his enormous experience of corporate social responsibility and law. We made the terms of reference for our teaching on the basis of an entirely different background in the business community and elsewhere. The first year has gone well and we are looking forward to many more.

Jan will now take the floor to shed some light on the issue of CSR and Law!!

Thank you all for your kind attention.

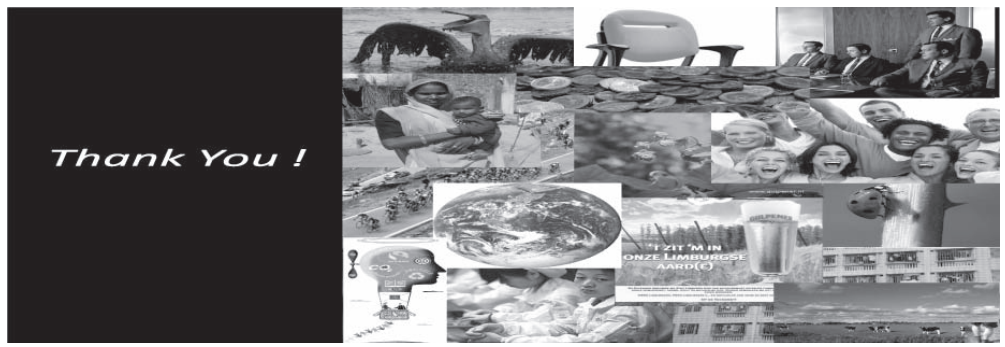




\section{Appendix 1: Overview of dimensions, aspects and issues in the content of corporate social responsibility (based on Dommerholt, 2009 and De Hoo et al., 2010)}

\section{Governance dimension}

Overarching principles: such as mission statements, ethical codes of conduct, integrity, codes of conduct and an overall management philosophy.

Overarching processes: such as establishing goals and priorities for performance, observing the law and regulations, management systems, accountants audits, control and supervision, management and administration / strategy / corporate policy / social policy / environmental policy / economic policy.

Stakeholders: such as the identification and selection of those parties crucial to the company, their interests, participation options, rights and communication.

Shareholders: such as confirming the rights of shareholders in general with the associated meticulous and fair: treatment, participation in decision making, profit sharing, registration of ownership, share transfer options, communication and the provision of information.

Boardroom: such as the careful recording and observance of: the key functions; crucial responsibilities; remuneration; composition in accordance with the guidelines relating to expertise, selection, the election and removal of members; communication with and between the supervisory board and the board of management, and between these boards and the company's senior management.

\section{Social dimension}

Employees: such as in employer / employee relations, terms and conditions of employment, freedom of association, diversity, equal opportunities and pay, health and safety, remuneration, education and training, a balance between work and private life.

Human rights: for instance with regard to fundamental rights, child labour, women's rights, forced labour, freedom of association, collective negotiation, discrimination, dealing with complaints, disciplinary measures.

Customers: such as marketing and advertising conduct, interaction with customers, customer rights and privacy, safety of products and services, information about products and services / price / quality / safety / specifications / distribution / use. 
Business relations / suppliers / providers of capital: such as monitoring and treatment in accordance with well-founded ethical rules of conduct and/or legislation and regulations, selection, payment, assessing environmental and social performance, collaboration.

Local community: such as respecting and/or improving the environment and social living standards, interaction and communication, lobbying, relationships with government, undertaking political activities, remuneration, bribery, corruption.

Competitors: such as the form and content of competitive behaviour in the market and the required openness towards authorities, form and content of responsibilities and conduct.

\section{Environmental dimension}

Emissions: such as sort of emission, magnitude and effects on soil / water / air quality, processing, imports/exports, reuse, reducing the level of toxicity, storage, transport, exports, prevention.

Waste: such as sort of emission, magnitude and effects on soil / water / air quality, processing, imports/exports, reuse, reducing the level of toxicity, storage, transport, export, prevention.

Living nature: such as protecting biodiversity and ecosystems, animal welfare and observing the principle of precaution.

Products and services: such as life cycle, raw materials efficiency, energy efficiency, environmental impact, reuse, removal, biodegradability, genetic modification, pace of innovation.

Research and technology: such as the amount of focus on a more sustainable development, realising incremental or radical innovations, increasing eco-efficiency and reducing environmental load.

Use of raw materials and production processes: such as the method of using and preserving: energy / space / materials (whether renewable or not) / water.

Transport / technology utilisation / logistics: related social, ecological footprint and energy footprint coupled with the entire production process.

Overall environmental policy: the extraction and exploitation of raw materials, reduction of impacts, recovery actions, external and internal contingency plans and accident control. 


\section{Economic dimension}

Market value: such as added value, utilisation of the various drivers of added value, the transparent presentation of economic performance, insight into the assets / obligations / income / costs / financial and operating results / cash flows / financial performance indicators and lastly the adequate implementation of rules of accounting and reporting. Economic dimensions: such as the dominance and size of the company in the market concerned, knowledge of the market, market position, market share, innovative strength.

Externalities: such as dealing with economic stability, employment, economic growth, income position, investments, unemployment, affect on / decline in income, economic impact on the community in the place of business. 
Prof. Drs. Ing. S.C. (Sybren) de Hoo

Corporate Social Responsibility and Innovation

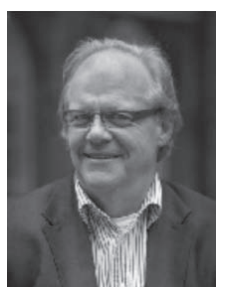

\section{Curriculum Vitae}

Background

Sybren de Hoo studied Civil Engineering at The Academy of Arts and Technical Sciences in Rotterdam, the Netherlands as well as Sociology including Environmental Sciences (cum laude) at the University of Leiden, the Netherlands. He designed, managed and executed practices and research with respect to those changes needed to bring about and accelerate sustainable development in non-governmental organisations, governmental organisations as well as in the business community. In particular he is interested in how sustainable development moves from the periphery to the core of organisations and as a result which changes occur in mission, strategy, policy, governance and key decision making processes as well as their impacts on business models, production processes, products, services and last but not least innovations. Sybren de Hoo worked mainly in the Netherlands but has also spent quite a few years abroad. He worked in France at the UNEP Industry and Environment Office in Paris, and in China at various locations as a designer/adviser/manager of cleaner production programmes on behalf of UNEP and in cooperation with Worldbank.

\section{Current positions}

Sybren de Hoo was appointed Professor of Corporate Sustainability and Innovation (2004) at the VU University Amsterdam, currently located at the Athena Institute of the Faculty of Earth and Life Sciences. In June 2010 he was also appointed Extraordinary Professor of Corporate Social Responsibility and Innovation at the Faculty of Law of Maastricht University. Sybren de Hoo has been actively involved in the design of the new Institute for Corporate Law, Governance and Innovation Policies (ICGI) at the Law Faculty of Maastricht University and became a Professorial Fellow of ICGI after its inception. 
With his ICGI colleague Prof. Mr. A.J.A.J. Eijsbouts he is co-responsible for the design and execution of the core course Corporate Social Responsibility in the International Master Programme Globalisation and Law.

Sybren de Hoo is a board member of the FACT Foundation (which promotes the application of sustainable energy solutions within local communities in developing countries) and member of the Jury of the Fair Trade City Program. Sybren de Hoo is member of the editorial board of an International Quarterly on CSR, Corporate Law and Innovation. Sybren de Hoo is director (since 1991) of his own consultancy company. 
